\title{
Selective laccase-catalyzed dimerization of phenolic compounds derived from lignin: Towards original symmetrical bio-based (bis) aromatic monomers
}

\author{
Audrey Llevot, Etienne Grau, Stéphane Carlotti, Stéphane Grelier, Henri Cramail
}

\begin{abstract}
A laccase-catalyzed process was developed to prepare, selectively, in high yield, dimers of lignin-based phenolic compounds without any purification. The influence of experimental parameters such as laccase loading, nature of solvent and the presence of oxygen on the conversion of vanillin was investigated. After the dimerization, the product obtained as a precipitate is filtered off and the solution containing the enzyme can be re-used several times, which improves the process economics. A phenolic-substrate screening reveals that such process enables to dimerize regioselectively, six ortho-methoxy-para-substituted phenols (vanillin, 4-hydroxy-3methoxybenzonitrile, acetovanillon, methyl vanillate, 2-methoxy-4-methylphenol, and eugenol) with yields ranging from $87 \%$ to $96 \%$ and one ortho-disubstituted phenol (2,6-dimethoxyphenol) with $80 \%$ yield.
\end{abstract}

\section{Introduction}

Nowadays, the partial replacement of fossil feedstocks by renewable resources attracts a thriving interest due to the petrol depletion and the growth of environmental concerns [1], [2]. In this purpose, new molecules and monomers issued from available biomass have to be developed [3], [4], [5], [6]. Lignin is the main source of aromatic bio-based substrates. Despite extensive researches on efficient ways of recovering aromatic products from lignin [7], nowadays, the only commercial process is the production of vanillin and vanillic acid by hydrothermal pretreatment under alkaline conditions of lignosulfonates, by-products of the sulfite paper industry [8], [9], [10], [11], [12].

Vanillin can be derived into divanillin, also called dehydrodivanillin, which is used mainly as flavoring [13] and antioxidant agent in food, cosmestic and pharmaceutical industry but can also be employed in microlithography [14] and in polymer synthesis [15], [16]. Over the years, divanillin has been synthesized by different methods. It is commonly produced by oxidative phenol-coupling using iron(III) chloride (FeCl ${ }_{3}$ ) or iron(II) sulfate $\left(\mathrm{FeSO}_{4}\right)$ [17], [18], [19], [20], [21], [22]. These non-sustainable processes require a high amount of iron catalyst, long reaction times and are not fully selective, thus generating a mixture of products and a difficult work up. In order to avoid the use of inorganic salts and toxic agents (sodium persulfate), enzymatic pathways were developed. In 1972, the formation of divanillin was observed for the first time after oxidation of vanillin in aqueous solution with peroxidase in the presence of hydrogen peroxide [23]. In 2004, Dordick and coworkers 
studied the structural diversity of peroxidase-catalyzed oxidation products of o-methoxyphenols, leading to oligomers in the case of vanillin [24]. Further improvements of the conditions were needed to reach a rather good selectivity in dimer formation [25].

Laccase is another very well-known class of oxidative enzyme studied since 1883 [26]. The latter were identified in several plants, insects, bacteria and fungus, where they have different biological functions [27], [28], [29]. Contrary to peroxidases, laccases employ dioxygen as oxidant. Currently, a lot of studies report the use of laccases as biocatalysts for the oxidation of functional moieties or the oxidative coupling of phenolic substrates [30], [31], [32], [33], [34], [35], [36], [37]. Laccases generate radical intermediates on phenolic compounds, which can undergo self-coupling reactions generally resulting in the formation of a mixture of products from dimers to higher oligomers. The selectivity of the coupling and the size of the oligomers depend on a broad range of parameters such as laccase source, $\mathrm{pH}$, temperature, substitution of the phenolic compound, solvents, etc. The use of laccases is limited due to their lack of selectivity. Recently, Beifuss and coworkers described a method on the coupling of vanillidene derivatives catalyzed by laccase from Trametes versicolor which provided the best result, in terms of yield/selectivity, of dimer synthesis by laccase catalysis [38]. Some specific substrates selectively led to one dimer in yield of over $80 \%$ but the authors did not investigate further the coupling reaction.

This study extends previous works in laccase-catalyzed dimer formation of ortho-methoxy-para-substituted phenols by improving dimerization process, product yields and extending the range of molecules studied for this reaction. Indeed, different reaction parameters such as reaction time, laccase loading and type of solvent were investigated on the example of vanillin. A refill procedure was also developed in order to recycle the catalyst solution. Afterwards, the same reaction conditions were applied on several phenolic substrates and the structures of the resulting products investigated.

\section{Results and discussion}

\subsection{Coupling process development and optimization on the example of vanillin}

Vanillin dimerization, catalyzed by laccase from Trametes versicolor, was performed at room temperature in a solution saturated in oxygen (Scheme 1). Prior to the addition of the acetate buffer $(90 \mathrm{vol} \%, \mathrm{pH} 5)$, vanillin was dissolved into acetone (10 vol\%). Hence, the reactant stays in solution while the resulting product precipitated. After addition of the laccase, the colorless solution turned yellow, which either indicate the formation of radicals or quinone structures. After few minutes, a brown solid precipitated. The first reactions were performed on $1.5 \mathrm{~g}$ scale of vanillin, employing $100 \mathrm{U}$ of laccase, in $200 \mathrm{~mL}$ solvent, for $24 \mathrm{~h}$. The precipitate was filtered off, washed with water and analyzed by mass spectrometry, NMR and HPLC (Figs. S1-S4, SI). These analyses revealed the selective formation of a symmetric dimer, divanillin $\mathbf{1}$ (Scheme 1). Particularly, the NMR spectroscopy analyses were in agreement with the study of Eswaran et al. [14]. 


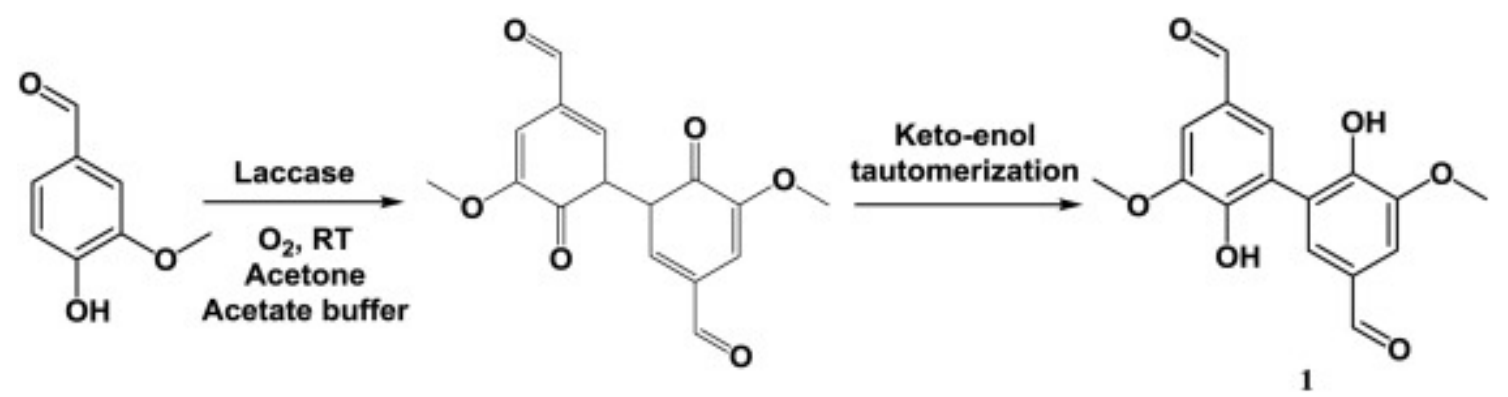

Scheme 1. Laccase-catalyzed vanillin dimerization, in acetone/acetate buffer $10 / 90$, under oxygen, at room temperature.

The selectivity and yield of coupling reactions catalyzed by laccase depend on the reaction conditions [39]. In this work, the influence of various parameters (enzyme loading, solvent, $\mathrm{pH}$ and saturation in oxygen) was investigated. The enzyme loading can be decreased down to $20 \mathrm{U}$ without affecting the yield of divanillin, which after $24 \mathrm{~h}$, remained over $80 \%$ (Fig. 1). Below this value, the yield decreased drastically to $50 \%$. Thus, the quantity of laccase for the following reactions was set at $20 \mathrm{U}$ for $1.5 \mathrm{~g}$ of substrate.

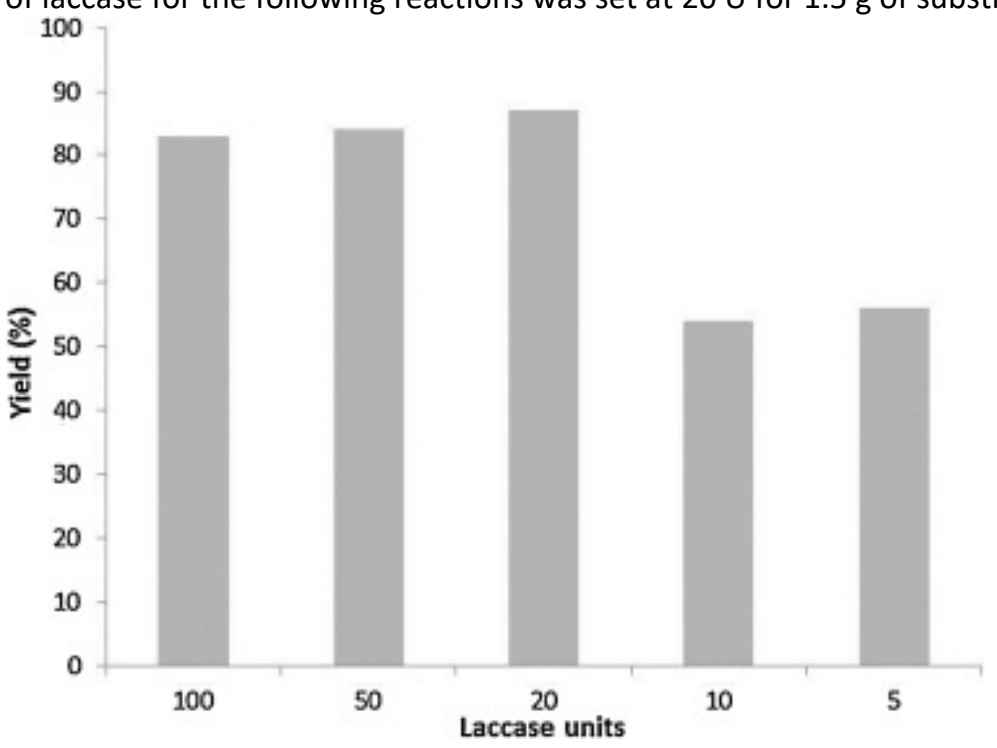

Fig. 1. Divanillin yields depending on laccase quantity for $1.5 \mathrm{~g}$ of vanillin, in $200 \mathrm{~mL}$ of solvent, after $24 \mathrm{~h}$. 
Vanillin conversion under different reaction conditions was followed by ${ }^{1} \mathrm{H}$ NMR spectroscopy (Fig. 2).

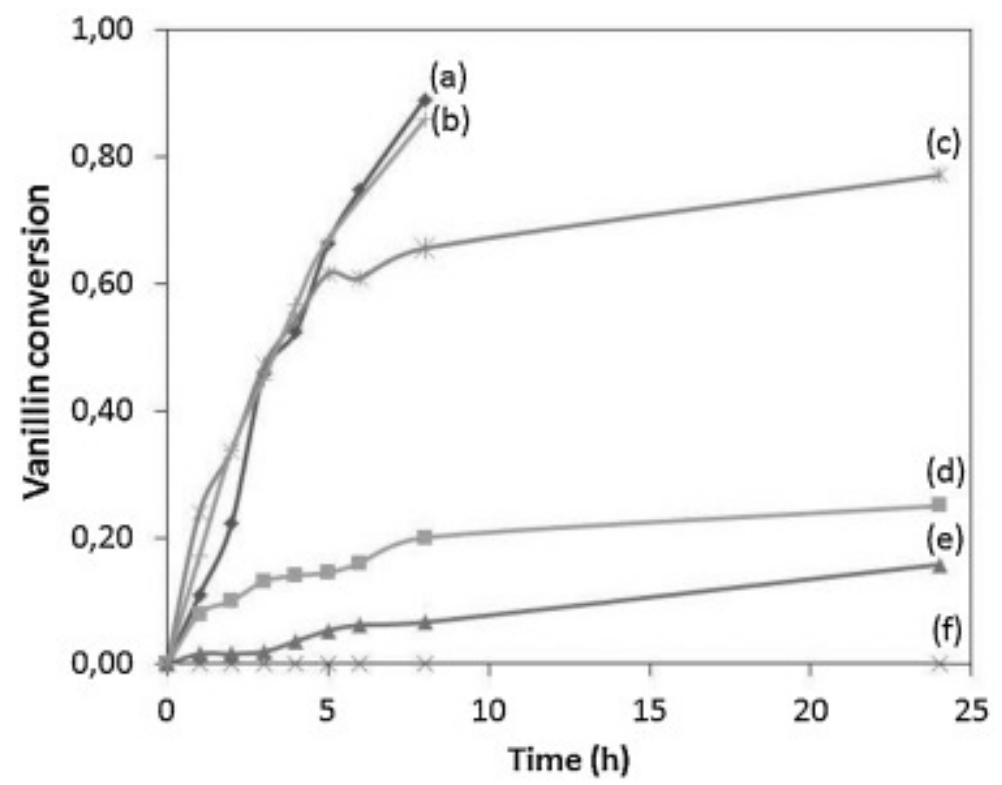

Fig. 2. Vanillin conversion versus time using data extracted from ${ }^{1} \mathrm{H}$ NMR spectra (aldehyde signal): different conditions: (a) 10\% acetone-90\% acetate buffer/ $\mathrm{O}_{2}$, (b) 10\% acetone-90\% acetate buffer/air, (c) $10 \%$ acetone- $-90 \%$ water $/ \mathrm{O}_{2}$, (d) $40 \%$ acetone- $-60 \%$ acetate buffer $/ \mathrm{O}_{2}$, (e) $10 \%$ acetone-90\% acetate buffer $/ \mathrm{N}_{2}$, (f) $70 \%$ acetone-30\% acetate buffer $/ \mathrm{O}_{2}$.

After $8 \mathrm{~h}, 85 \%$ conversion of vanillin into divanillin was achieved for an acetone/acetate buffer ratio of 10/90 under $\mathrm{O}_{2}$ bubbling (a). In the following samples, the concentration of vanillin in the solution was too low to be detected (Fig. S5, SI). Instead of bubbling $\mathrm{O}_{2}$, the reaction was carried out in a beaker with a large surface in contact with air, under vigorous stirring. The vanillin conversion (b) was similar to the conversion obtained in a solution saturated in oxygen (a). However, if the quantity of $\mathrm{O}_{2}$ in the solution is limited by bubbling $\mathrm{N}_{2}$ into the solution, after $25 \mathrm{~h}$, the vanillin conversion (d) only reached $25 \%$. The saturation of the solution with $\mathrm{O}_{2}$ is thus a key parameter to reach high yield in divanillin.

When the acetate buffer is substituted by water, the conversion profile (c) follows the reference curve (a) until $5 \mathrm{~h}$ of reaction. Beyond this time, the reaction speed decreased and, only $75 \%$ conversion was achieved after $24 \mathrm{~h}$. An increase of the $\mathrm{pH}$ from 5-7 was observed after the reaction was stopped, that can explain the low conversion in the last hours. Indeed, the optimal pH zone for laccase ranges from 4-6; off this range, the laccase activity decreases.

The amount and nature of solvent also influence the laccase activity. Increasing the acetone/buffer ratio to $40 \%$ dramatically decreased the reaction speed (e). When the reaction was carried out with $70 \%$ of acetone, no conversion of the starting compound was observed (f). It is thus crucial to use the minimum amount of solvent required to dissolve the starting material in order to achieve high yields. Acetone can be substituted by other organic solvents provided the latter do not inhibit the laccase. However, depending on the solvent and 
quantity, the reaction yield can be affected [40], [41]. For instance, 10\% of DMSO was tested as alternative cosolvent and led to a yield around $90 \%$ after $8 \mathrm{~h}$.

In this process, the recovery of divanillin as a precipitate presents three advantages: (i) as vanillin is soluble into the solution, the purity of the obtained dimer is very high ( $95 \%$ by NMR) and no purification is needed (ii) the precipitation shifts the reaction equilibrium to divanillin formation and prevent divanillin from further phenolic coupling, (iii) after filtration, the filtrate can be re-used for a new reaction. Indeed, after reaction, the precipitate was filtered off. The filtrate, which still contains the laccase, was saturated again with oxygen and another batch of vanillin was added. After few seconds, vanillin was dissolved and after few minutes, a brown solid started to precipitate (Fig. S6, SI). Even after 8 runs of recharging the catalyst with the substrat, more than $80 \%$ of product was isolated (Fig. 3). The combination of the easy recovery method without a marginal loss of activity constitutes the main advantage of this process.

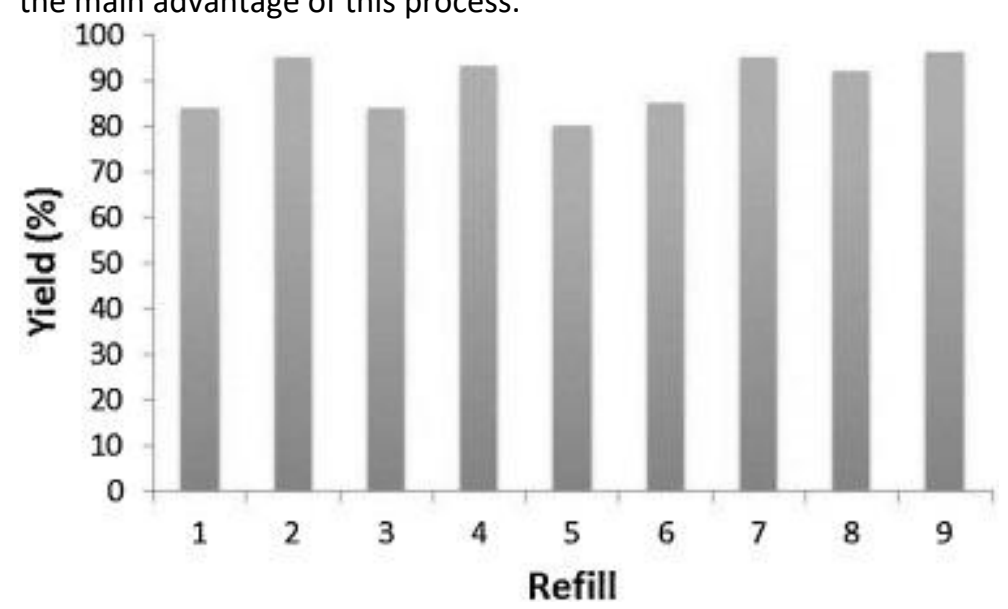

Fig. 3. Divanillin yield, after $24 \mathrm{~h}$ of reaction under optimized conditions ( $20 \mathrm{U}$, acetate buffer) for the first reaction plus 8 refills.

\subsection{Substrate screening}

The dimerization procedure developed previously was applied on several substrates with the objective to selectively produce dimers. First, the dimerization of ortho-methoxy phenols with different para substituents was investigated.

The reaction of some of the phenols led to complex mixtures. Vanillic acid led to oligomers up to 5 units, probably due to a decarboxylation reaction (Fig. S7, SI). Indeed, in literature, decarboxylation reactions were reported for the reaction of syringic acid with laccase (Fig. S8 SI). The postulated reaction mechanism is explained by the formation of phenoxy radicals which can couple each other to give the quinoide-type intermediates. The dimer is formed by release of carbon dioxide from the intermediate. Further couplings lead to the formation of poly(phenylene oxide) [42]. Similarly, under our reaction conditions, poly(phenylene oxide) was produced from syringic acid (Fig. S9, SI). The coupling of vanillyl alcohol resulted in a mixture of dimers, trimers and tetramers (Fig. S10, SI). The latter has already been reported in literature and, depending on the conditions, dimers with three different structures, trimers or tetramers were produced [43], [44]. In the case of substrates bearing 
a para substituent containing a double bond conjugated to the aromatic ring, the radical generated by laccase oxidation is delocalized over the extended $\pi$-system. This conjugation leads to the formation of further coupling products. In this case, the formation of $\beta-5$ dimers, $5,5^{\prime}$ dimer, phenylcoumaran and $\beta-\beta^{\prime}$ dimers were reported in literature [45], [46], [47], [48]. These dimers further recombine with other radical species, resulting in complex oligomeric structures. We investigated the coupling of coniferaldehyde (Fig. S11, SI), 2-methoxy-4vinylphenol (Fig. S12, SI) and isoeugenol (Fig. S13, SI) which, respectively, led to a complex mixture of dimers to pentamers, oligomers up to $6000 \mathrm{~g} / \mathrm{mol}$ and mainly dimers (90\%) plus oligomers (10\%) in which coumaran and $\beta-\beta^{\prime}$ units were observed (Table 1).

Table 1. Laccase-catalyzed oxidative coupling of ortho mono substituted phenol.

\begin{tabular}{lll}
\hline Starting compound & Final product & Yield $^{\mathbf{a}}(\mathbf{\%})$ \\
\hline Vanillic acid & Oligomers up to 5 units & 40 \\
Vanillyl alcohol & Mixture of dimers and tetramers & 85 \\
Coniferaldehyde & Several dimers, trimers and tetramers & 92 \\
2-Methoxy-4-vinylphenol & Oligomers up to 6000 g/mol & 83 \\
Isoeugenol & Mainly dimers and oligomers & 85 \\
\multicolumn{1}{c}{ a Yield of the isolated precipitate. } & &
\end{tabular}

The selective formation of dimers by $\mathrm{C} \_\mathrm{C}$ coupling was achieved under the above mentioned conditions with six ortho-methoxy-para-substituted phenols bearing aldehyde, nitrile, ketone, ester, methyl and alkylene as para substituents. 4-Hydroxy-3-methoxybenzonitrile dimer, 2, diacetovanillon, 3, methyl vanillate dimer, 4, 2methoxy-4-methylphenol dimer, 5, and dieugenol, 6, selectively precipitated with yields ranging from $87 \%$ to 96\% (Scheme 2). 
<smiles>COc1cc(C=O)cc(-c2cc(C=O)cc(OC)c2O)c1O</smiles><smiles>C=CCc1cc(OC)c(O)c(-c2cc(CC=C)cc(OC)c2O)c1</smiles>

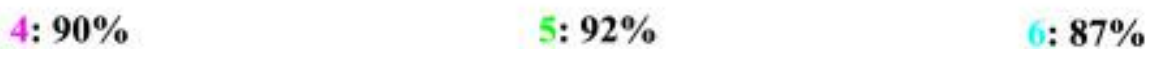

Scheme 2. Products of laccase-catalyzed selective dimerization of vanillin, 4-hydroxy-3methoxybenzonitrile, acetovanillon, methylvanillate, 2-methoxy-4-methyl phenol and eugenol.

The HPLC profiles of each reaction product show a single peak and the mass spectrum reveals the formation of the corresponding dimer (see SI). The symmetry of the molecule was demonstrated by NMR spectroscopy and fully assigned (Fig. 4). The main difference between substrate and dimer is the disappearance of an aromatic proton. 


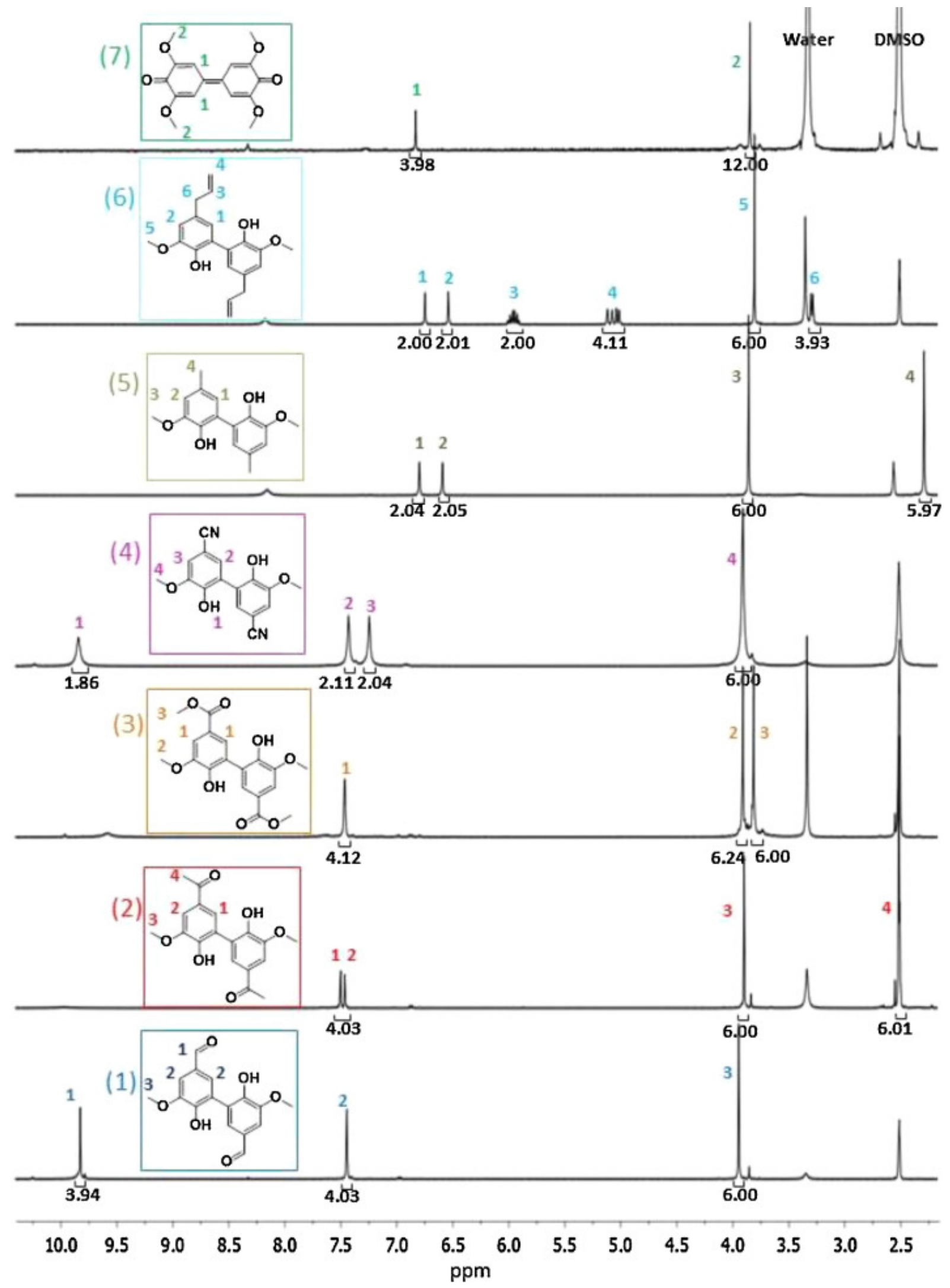

Fig. $\quad 4 .{ }^{1} \mathrm{H} \quad \mathrm{NMR}$ spectra of the dimers obtained by selective oxidative coupling catalyzed by laccase of vanillin (1), acetovanillon (2), methylvanillate (3), 4-hydroxy-3-methoxybenzonitrile (4), 2methoxy-4-methyl phenol (5), eugenol (6) and of 2,6-dimethoxyphenol (7). 
Furthermore, the coupling of 2,6-dimethoxyphenol was also investigated at the aforementioned conditions. The reaction led selectively to the formation of dimer $\mathbf{8}$ in $80 \%$ yield, contrary to a previously reported study, where four demethylated products were also observed employing laccase from Trametes pubescens [49]. During the oxidative coupling of 2,6-dimethoxyphenol, Q1 is produced by recombination of two para radical species. Further reaction of this compound with laccase can lead either to its re-aromatization into compound $\mathbf{8}$ or to the formation of the very stable quinone $\mathbf{7}$ (Scheme 3) which show different molar masses. In the literature, depending on the study, the formation of 8 or 7 was reported [49], [50]. In this experiment, mass spectroscopy resulted in a molar mass of $304 \mathrm{~g} / \mathrm{mol}$ attributed to the quinone 7 . The nature of the ortho substituents plays an important role in the coupling selectivity. For instance, the coupling of 2,6-dimethylphenol led to a mixture of dimers (around 15\%) and oligomers of phenylene oxide with a molar mass of $1300 \mathrm{~g} / \mathrm{mol}$. This difference in selectivity may be attributed to different inductive effects.

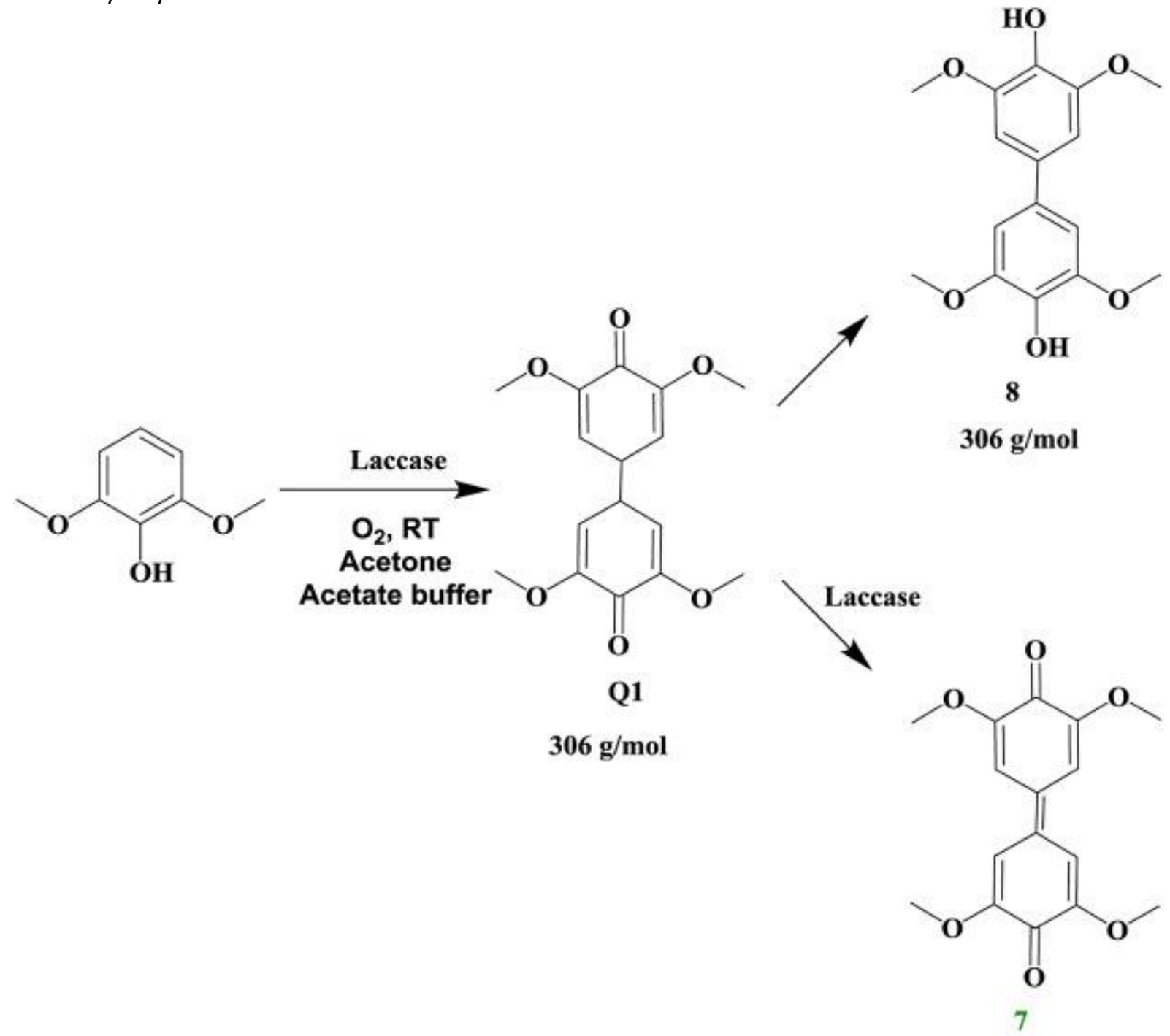

$304 \mathrm{~g} / \mathrm{mol}$

Scheme 3. Laccase-catalyzed dimerization of 2,6-dimethoxyphenol. 


\section{Conclusion}

A green and easy way to synthesize divanillin in high yield (95\%) and purity was developed and scale up to $15 \mathrm{~g}$. This process presents several advantages: (i) the divanillin formation occurs at room temperature, under oxygen which could be replaced by air, (ii) the employed (co) solvent, 10\% of acetone, shows a low toxicity, (iii) the product extraction is easy and the purity is high (95\%) because the solvent conditions enable the reactant solubility while the so-formed dimer precipitates, (iv) a low quantity of enzyme is required and the catalystcontaining solution can be re-used to dimerize a new batch of substrate. Some parameters such as a minimal amount of organic solvent, sufficient oxygen content and the use of a buffer solution appeared to be crucial to reach a high vanillin conversion. Furthermore, this dimerization procedure was extended to several substrates. In addition to vanillin, the coupling of 4-hydroxy-3-methoxybenzonitrile, methyl vanillate, 4-methyl-2methoxyphenol, 2,6-dimethoxyphenol and eugenol yielded selectively dimers with yields over $85 \%$, with a high purity and without further purification. Such a platform of symmetrical and functional aromatic dimers is of high interest for the design of novel rigid (semi) aromatic bio-based polymers.

\section{Experimental}

\subsection{Material}

Laccase from Trametes versicolor, acetic acid, eugenol, isoeugenol, 2,6-dimethoxyphenol, coniferaldehyde and 2-methoxy-4-vinylphenol were purchased from Sigma-Aldrich. Vanillic acid, vanillin and 2-methyl-4methoxyphenol were purchased from Alfa Aesar. Acetovanillon was purchased from Acros Organics. All products and solvents (reagent grade) were used as received.

\subsection{Instrumentations}

All NMR experiments were performed at $298 \mathrm{~K}$ on a Bruker Avance 400 spectrometer operating at $400 \mathrm{MHz}$, in DMSO-d6. Size exclusion chromatography (SEC) analyses were performed in THF $\left(40^{\circ} \mathrm{C}\right)$ on a PL-GPC 50 plus Integrated GPC from Polymer laboratories-Varian with a series of four columns from TOSOH (TSKgel TOSOH: HXLL (guard column $6.0 \mathrm{~mm} \mathrm{ID} \times 4.0 \mathrm{~cm} \mathrm{~L}) ; \mathrm{G} 4000 \mathrm{HXL}(7.8 \mathrm{~mm}$ ID $\times 30.0 \mathrm{~cm} \mathrm{~L}) ; \mathrm{G} 3000 \mathrm{HXL}(7.8 \mathrm{~mm} \mathrm{ID} \times 30.0 \mathrm{~cm} \mathrm{~L})$ and $\mathrm{G} 2000 \mathrm{HXL}(7.8 \mathrm{~mm} \quad \mathrm{ID} \times 30.0 \mathrm{~cm} \mathrm{~L}))$. The elution of the filtered samples was monitored using simultaneous refractive index and UV detection. The elution times were converted to molar mass using a calibration curve based on low dispersity polystyrene standards. HPLC was performed using a Spectra system instrument fitted with a Phenomenex Luna $5 \mu$ C18 100A column and compounds were detected with a Sedere Sedex $85 \mathrm{LT}$ ELSD detector at $40^{\circ} \mathrm{C}(G=4$, filter OFF). These analyses were performed in acetonitrile at a flow rate of $1 \mathrm{~mL} / \mathrm{min}$. Mass (FD) spectra were performed by the Centre d'Etudes Structurales et d'Analyses des Molécules, CESAMO (Bordeaux, France). The measurements were carried out on a TOF mass spectrometer 
AccuTOF GCv using an FD emitter with an emitter voltage of $10 \mathrm{kV}$. One to two microliters solution of the compound is deposited on a $13 \mathrm{~mm}$ emitter wire.

\subsection{Experimental procedure}

\subsubsection{Synthesis of methylvanillate}

Vanillic acid $(15.0 \mathrm{~g}, 0.09 \mathrm{~mol})$ was dissolved in methanol $(75 \mathrm{~mL})$. Sulfuric acid $(2.1 \mathrm{~mL})$ was added and the mixture was stirred and warmed to reflux for $8 \mathrm{~h}$. After evaporation of methanol, the solid was dissolved in ethylacetate $(60 \mathrm{~mL})$, washed with a $\mathrm{NaHCO}_{3}$ solution $(30 \mathrm{~mL})$, water (2 times) and brine (1 time). The organic phase was evaporated under reduced pressure. Yield: $90 \%$.

${ }^{1} \mathrm{H} \mathrm{NMR}\left(400 \mathrm{MHz}, \mathrm{CDCl}_{3}, \delta(\mathrm{ppm})\right): \delta 7.45(\mathrm{~m}, 2 \mathrm{H}, \mathrm{Ar}), 6.88(\mathrm{~d}, 1 \mathrm{H}, \mathrm{Ar}), 3.81\left(\mathrm{~s}, 3 \mathrm{H}, \mathrm{OCH}_{3}\right), 3.79\left(\mathrm{~s}, 3 \mathrm{H}, \mathrm{OCH}_{3}\right.$ ester). ${ }^{13} \mathrm{C} \mathrm{NMR}\left(400 \mathrm{MHz}, \mathrm{CDCl}_{3}, \delta(\mathrm{ppm})\right): \delta$ 166,03 (OCH 3 ester), $151.22(\mathrm{Ar}-\mathrm{C}), 147.20(\mathrm{Ar}-\mathrm{C}), 123.38(\mathrm{Ar}-\mathrm{C}), 120.30$ ( $\mathrm{Ar}-\mathrm{C}), 115.13(\mathrm{Ar}-\mathrm{C}), 112.42(\mathrm{Ar}-\mathrm{C}), 55.27\left(\mathrm{OCH}_{3}\right), 51.60\left(\mathrm{OCH}_{3}\right.$ ester $)$.

\subsubsection{4-Hydroxy-3-methoxybenzonitrile synthesis}

Vanillin $(750 \mathrm{mg}, 5 \mathrm{mmol})$ was dissolved in acetic acid $(15 \mathrm{~mL}) \cdot \mathrm{NH}_{2} \mathrm{OH} \cdot \mathrm{HCl}(520 \mathrm{mg}, 7.5 \mathrm{mmol})$ was added and the mixture was stirred and warmed at $110^{\circ} \mathrm{C}$ for $2 \mathrm{~h}$. The reaction was stopped by adding $\mathrm{H}_{2} \mathrm{O}$; the organic product extracted using $\mathrm{CH}_{2} \mathrm{Cl}_{2}$, dried and purified by flash chromatography (Ethyl acetate/cyclohexane 3/7). Yield: 80\%. ${ }^{1} \mathrm{H}$ NMR (400 MHz, DMSO, $\delta$ (ppm): $\delta 7.34$ (1H, s, Ar), 7.27 (d, 1H Ar), 6.88 (d, $1 \mathrm{H} \mathrm{Ar}$ ) 3.81 (s, OCH $)_{3}$. ${ }^{13} \mathrm{C}$ NMR (400 MHz, DMSO, $\left.\delta(\mathrm{pm})\right) \delta 151.79(\mathrm{Ar}-\mathrm{C}), 148.41$ (Ar-C), $126.92(\mathrm{Ar}-\mathrm{C}), 120.06$ (CN), $116.68(\mathrm{Ar}-\mathrm{C})$, $115.56(\mathrm{Ar}-\mathrm{C}) ; 101.1(\mathrm{Ar}-\mathrm{C})$ 1, $56.39\left(\mathrm{OCH}_{3}\right)$.

\subsubsection{Enzyme activity}

The activity of commercial laccase from Trametes versicolor was determined spectrophotometrically by monitoring the oxidation of 2,2'-azino-bis-(3-ethylbenzthiazoline-6-sulfonic acid) (ABTS, $\varepsilon=36,000 \mathrm{~mol}^{-1} \mathrm{~cm}^{-2}$ ). The reaction mixture contained $0.04 \mathrm{mM}$ of ABTS, $50 \mathrm{mM}$ of acetate buffer ( $\mathrm{pH}$ 5.0) and laccase. The absorbance change was monitored at $414 \mathrm{~nm}$ for $5 \mathrm{~min}$ at room temperature [51]. The amount of laccase that generated $1 \mu \mathrm{mol}$ of ABTS radical cation per minute was defined as one unit, $U$. The activity of laccase batch used in this study was evaluated at $1.6 \mathrm{U} / \mathrm{mg}$.

4.3.4. General procedure for dimerization: synthesis of dimers 1-7

A solution of phenol substrate $(1-7)(1.5 \mathrm{~g})$ in acetone $(20 \mathrm{~mL})$ was added to NaOAc buffer $(180 \mathrm{~mL}, 0.1 \mathrm{M}, \mathrm{pH}$ 5.0). $\mathrm{O}_{2}$ was bubbled into the solution for $5 \mathrm{~min}$. Laccase from Trametes versicolor $(20 \mathrm{U}, 12.4 \mathrm{mg}$ ) was added and the reaction was stirred at room temperature for $24 \mathrm{~h}$. The precipitate was filtered off the solution and the product dried overnight at $80^{\circ} \mathrm{C}$ under vacuum. 
This procedure was adapted on $15 \mathrm{~g}$ in the case of vanillin.

Divanillin (1): MW = $302 \mathrm{~g} / \mathrm{mol}$, yield: $96 \%$.

${ }^{1} \mathrm{H}$ NMR $\left(400 \mathrm{MHz}, \mathrm{CDCl}_{3}, \delta(\mathrm{ppm})\right): \delta 9.85$ (s, CHO), 7.50 (s, 2H Ar), $4.00\left(\mathrm{~s}, \mathrm{OCH}_{3}\right)$.

${ }^{13} \mathrm{C} \mathrm{NMR}\left(400 \mathrm{MHz}, \mathrm{CDCl}_{3}, \delta(\mathrm{ppm})\right): \delta 191.04(\mathrm{CHO}), 150.70(\mathrm{Ar}-\mathrm{C}), 147.95(\mathrm{Ar}-\mathrm{C}), 128.30(\mathrm{Ar}-\mathrm{C}), 127.69(\mathrm{Ar}-\mathrm{C})$, $124.52(\mathrm{Ar}-\mathrm{C}), 109.10(\mathrm{Ar}-\mathrm{C}), 55.88\left(\mathrm{OCH}_{3}\right)$.

4-Hydroxy-3-methoxybenzonitrile $\operatorname{dimer}(2): \mathrm{MW}=296 \mathrm{~g} / \mathrm{mol}$, yield: $95 \%$.

${ }^{1} \mathrm{H}$ NMR (400 MHz, $\left.\mathrm{CDCl}_{3}, \delta(\mathrm{ppm})\right): \delta 9.91(\mathrm{~s}, 2 \mathrm{H}, \mathrm{HO}), 7.57(\mathrm{~s}, 2 \mathrm{H}, \mathrm{Ar}), 7.42(\mathrm{~s}, 2 \mathrm{H}, \mathrm{Ar}), 3,93\left(\mathrm{~s}, 6 \mathrm{H}, \mathrm{OCH}_{3}\right)$.

$\left.{ }^{13} \mathrm{C} \mathrm{NMR}\left(400 \mathrm{MHz}, \mathrm{CDCl}_{3}, \delta(\mathrm{ppm})\right): \delta 148.63 \mathrm{Ar}-\mathrm{C}\right), 147.85(\mathrm{Ar}-\mathrm{C}), 128.05(\mathrm{Ar}-\mathrm{C}), 124.56(\mathrm{Ar}-\mathrm{C}), 119.45(\mathrm{Ar}-\mathrm{C})$, $114.03(\mathrm{Ar}-\mathrm{C}), 100.30(\mathrm{CN}), 56.15\left(\mathrm{OCH}_{3}\right)$.

Diacetovanillon (3): $\mathrm{MW}=330 \mathrm{~g} / \mathrm{mol}$, yield: $92 \%$.

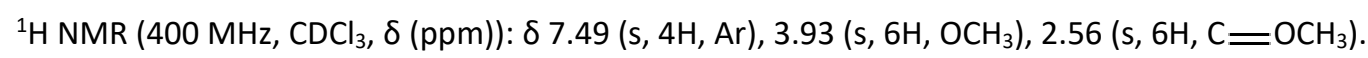

${ }^{13} \mathrm{C} \mathrm{NMR}\left(400 \mathrm{MHz}, \mathrm{CDCl}_{3}, \delta(\mathrm{ppm})\right): \delta 196.07(\mathrm{OCH}), 149.22(\mathrm{Ar}-\mathrm{C}), 147.06(\mathrm{Ar}-\mathrm{C}), 127.81(\mathrm{Ar}-\mathrm{C}), 124.23(\mathrm{Ar}-\mathrm{C})$, $124.04(\mathrm{Ar}-\mathrm{C}), 109.03(\mathrm{Ar}-\mathrm{C}), 55.76\left(\mathrm{OCH}_{3}\right), 26.25\left(\mathrm{CH}_{3}\right)$.

Dimethyl divanillate (4): $\mathrm{MW}=362 \mathrm{~g} / \mathrm{mol}$, yield: $90 \%$.

${ }^{1} \mathrm{H} \mathrm{NMR}\left(400 \mathrm{MHz}_{2} \mathrm{CDCl}_{3}, \delta(\mathrm{ppm})\right): \delta 9.60(\mathrm{~s}, 2 \mathrm{H}, \mathrm{HO}), 7.46(\mathrm{~s}, 4 \mathrm{H}, \mathrm{Ar}), 3.90\left(\mathrm{~s}, 6 \mathrm{H}, \mathrm{OCH}_{3}\right), 3.80\left(\mathrm{~s}, 6 \mathrm{H}, \mathrm{OCH}_{3}\right.$ ester). ${ }^{13} \mathrm{C}$ NMR (400 MHz, $\left.\mathrm{CDCl}_{3}, \delta(\mathrm{ppm})\right): \delta$ 166,04 (OCH $\mathrm{OCster}_{3}, 148.60(\mathrm{Ar}-\mathrm{C}), 147.27(\mathrm{Ar}-\mathrm{C}), 125.25(\mathrm{Ar}-\mathrm{C})$, 123.93( $\mathrm{Ar}-\mathrm{C}), 119.21(\mathrm{Ar}-\mathrm{C}), 110.89(\mathrm{Ar}-\mathrm{C}), 55.97\left(\mathrm{OCH}_{3}\right), 51.75\left(\mathrm{OCH}_{3}\right.$ ester $)$.

2-Methoxy-4-methyl phenol dimer (5): $\mathrm{MW}=274 \mathrm{~g} / \mathrm{mol}$, yield: $92 \%$.

${ }^{1} \mathrm{H} \mathrm{NMR}\left(400 \mathrm{MHz}, \mathrm{CDCl}_{3}, \delta(\mathrm{ppm})\right): \delta 6.73(\mathrm{~s}, 2 \mathrm{H}, \mathrm{Ar}), 6.53(\mathrm{~s}, 2 \mathrm{H}, \mathrm{Ar}), 3.79\left(\mathrm{~s}, 6 \mathrm{H}, \mathrm{OCH}_{3}\right), 2.23\left(\mathrm{~s}, 6 \mathrm{H}, \mathrm{CH}_{3}\right)$.

${ }^{13} \mathrm{C} \mathrm{NMR}\left(400 \mathrm{MHz}, \mathrm{CDCl}_{3}, \delta(\mathrm{ppm})\right): 147.52(\mathrm{Ar}-\mathrm{C}), 140.99(\mathrm{Ar}-\mathrm{C}), 126.92(\mathrm{Ar}-\mathrm{C}), 125.68(\mathrm{Ar}-\mathrm{C}), 123.04(\mathrm{Ar}-\mathrm{C})$, $111.61(\mathrm{Ar}-\mathrm{C}), 55.85\left(\mathrm{OCH}_{3}\right), 20.65\left(\mathrm{CH}_{3}\right)$.

Dieugenol (6): $\mathrm{MW}=326 \mathrm{~g} / \mathrm{mol}$, yield: $87 \%$.

${ }^{1} \mathrm{H} \mathrm{NMR}\left(400 \mathrm{MHz}, \mathrm{CDCl}_{3}, \delta(\mathrm{ppm})\right): \delta 6.74$ (s, 2H Ar), 6.52 (s, 2H Ar), $5.94\left(\mathrm{q}, 2 \mathrm{H} \mathrm{CH}-\mathrm{CH}_{2}\right), 5.03\left(\mathrm{~d}, 4 \mathrm{H} \mathrm{CH}-\mathrm{CH}_{2}\right)$, $3.79\left(\mathrm{~s}, \mathrm{OCH}_{3}\right), 3.27(\mathrm{~d}, 2 \mathrm{H} \mathrm{CH}$ ).

${ }^{13} \mathrm{C} \mathrm{NMR}\left(400 \mathrm{MHz}, \mathrm{CDCl}_{3}, \delta(\mathrm{ppm})\right): \delta 147.80(\mathrm{Ar}-\mathrm{C}), 141.62(\mathrm{Ar}-\mathrm{C}), 138.38\left(\mathrm{CH}-\mathrm{CH}_{2}\right), 129.57(\mathrm{Ar}-\mathrm{C}), 125.67(\mathrm{Ar}-$ C), $122.62(\mathrm{Ar}-\mathrm{C}), 115.28\left(\mathrm{CH}-\mathrm{CH}_{2}\right), 105.56(\mathrm{Ar}-\mathrm{C}), 55.64\left(\mathrm{OCH}_{3}\right), 39.19\left(\mathrm{CH}_{2}\right)$.

2,6-Dimethoxyphenol dimer (7): $\mathrm{MW}=304 \mathrm{~g} / \mathrm{mol}$, yield: $80 \%$.

${ }^{1} \mathrm{H}$ NMR (400 MHz, $\left.\mathrm{CDCl}_{3}, \delta \mathrm{ppm}\right): \delta 8.32(\mathrm{~s}, 2 \mathrm{H}, \mathrm{HO}), 6.82(\mathrm{~s}, 4 \mathrm{H}, \mathrm{Ar}), 3,84\left(\mathrm{~s}, 12 \mathrm{H}, \mathrm{OCH}_{3}\right)$.

4.3.5. Refill procedure

After filtration of the dimer, the solution is kept, refilled with $1.5 \mathrm{~g}$ of vanillin $\mathrm{O}_{2}$ again. After $24 \mathrm{~h}$, the precipitate is filtered and the refill procedure followed again up to 9 times.

4.3.6. Conversion investigation 
Dioxane was used as an internal reference. $0.4 \mathrm{~mL}$ of solution is sampled regularly, filtered and diluted in acetone-d6. The samples are analyzed by ${ }^{1} \mathrm{H}$ NMR spectroscopy. The vanillin conversion is extracted from the ratio of $\mathrm{CHO}$ peak integration at $9.81 \mathrm{ppm}$ and the dioxane peak integration at $3.63 \mathrm{ppm}$.

Details experiments Fig. 3:

(a) $10 \%$ acetone- $90 \%$ acetate buffer $/ \mathrm{O}_{2:}$ general procedure described above.

(b) $10 \%$ acetone- $90 \%$ acetate buffer/air: the solution is not bubbled with $\mathrm{O}_{2}$ but is carried out under high stirring in an open beaker.

(c) $10 \%$ acetone $-90 \%$ water $/ \mathrm{O}_{2}$ : the acetate buffer is replaced by distilled water.

(d) $40 \%$ acetone $-60 \%$ acetate buffer $/ \mathrm{O}_{2}$ : the solvent ratio is modified.

(e) $10 \%$ acetone- $90 \%$ acetate buffer $/ \mathrm{N}_{2}$ : the solution is not bubbled with $\mathrm{O}_{2}$ but with $\mathrm{N}_{2}$.

(f) $70 \%$ acetone- $30 \%$ acetate buffer $/ \mathrm{O}_{2}$ : the solvent ratio is modified.

\section{References}

[1] C. Okkerse, H. van Bekkum From fossil to green Green Chem., 1 (1999), pp. 107-114

[2] R.A. Sheldon Green and sustainable manufacture of chemicals from biomass: state of the art Green Chem., 16 (2014), pp. 950-963

[3] G. Lligadas, J.C. Ronda, M. Galià, V. Cádiz Renewable polymeric materials from vegetable oils: a perspective Mater. Today, 16 (2013), pp. 337-343

[4] C. Xu, R.A.D. Arancon, J. Labidi, R. Luque Lignin depolymerisation strategies: towards valuable chemicals and fuels Chem. Soc. Rev., 43 (2014), pp. 7485-7500

[5] R. Auvergne, S. Caillol, G. David, B. Boutevin, J.-P. Pascault Biobased thermosetting epoxy: present and future Chem. Rev., 114 (2013), pp. 1082-1115

[6] F.H. Isikgor, C.R. Becer Lignocellulosic biomass: a sustainable platform for the production of bio-based chemicals and polymers Polym. Chem. (2015), 10.1039/C5PY00263J

[7] M.P. Pandey, C.S. Kim Lignin depolymerization and conversion: a review of thermochemical methods Chemi. Eng. Technol., 34 (2011), pp. 29-41

[8] I.A. Pearl Vanillin from lignin materials J. Am. Chem. Soc., 64 (1942), pp. 1429-1431

[9] C.O. Tuck, E. Pérez, I.T. Horváth, R.A. Sheldon, M. Poliakoff Valorization of biomass: deriving more value from waste Science, 337 (2012), pp. 695-699

[10] H. Rasmussen, H.R. Sørensen, A.S. Meyer Formation of degradation compounds from lignocellulosic biomass in the biorefinery: sugar reaction mechanisms Carbohydr. Res., 385 (2014), pp. 45-57

[11] H.-R. Bjørsvik, F. Minisci Fine Chemicals from lignosulfonates. 1. Synthesis of vanillin by oxidation of lignosulfonates Organ. Process Res. Dev., 3 (1999), pp. 330-340

[12] A.W. Pacek, P. Ding, M. Garrett, G. Sheldrake, A.W. Nienow Catalytic conversion of sodium lignosulfonate to vanillin: engineering aspects. part 1. Effects of processing conditions on vanillin yield and selectivity Ind. Eng. Chem. Res., 52 (2013), pp. 8361-8372

[13] I. Reiss, I.L. Gatfield, G. Krammer, A. Clerc, G. Kindel, Use of divanillin as a flavouring agent, in patent US20060286237 A1, (2006).

[14] J.L. Manoj Gaur, V.R. Balakrishnan, P. Raghunathan, a.S.V. Eswaran Dehydrodivanillin: multi-dimensional NMR spectral studies, surface morphology and electrical characteristics of thin film Bull. Korean Chem. Soc., 30 (2009), pp. 2895-2898

[15] A.S. Amarasekara, A. Razzaq Vanillin-based polymers-part II: synthesis of schiff base polymers of divanillin and their chelation with metal ions Polym. Sci., 2012 (2012), pp. 1-6

[16] A.S. Amarasekara, B. Wiredu, A. Razzaq Vanillin based polymers: I. An electrochemical route to polyvanillin Green Chem., 14 (2012), pp. 2395-2397

[17] H. Yamamoto, T. Hoshino, T. Uchiyama Convenient preparation and quantification of 5,5'-diferulic acid Biosci. Biotechnol. Biochem., 63 (1999), pp. 390-394

[18] F. Tiemann, Berichte der deutschen chemischen Gesellschaft, Ueber eine charakteristische reaction des vanillins, 18 (1885) 3493-3496. 
[19] K. Elbs, H.J. Lerch Über Dehydrodivanillin J. Prakt. Chem., 93 (1916), pp. 1-6

[20] D.R. Kelly, S.C. Baker, D.S. King, D.S. de Silva, G. Lord, J.P. Taylor Studies of nitrile oxide cycloadditions, and the phenolic oxidative coupling of vanillin aldoxime by Geobacillus sp. DDS012 from Italian rye grass silage Org. Biomol. Chem., 6 (2008), pp. 787-796

[21] M. Delomenède, F. Bedos-Belval, H. Duran, C. Vindis, M. Baltas, A. Nègre-Salvayre Development of novel antiatherogenic biaryls: design, synthesis, and reactivity J. Med. Chem., 51 (2008), pp. 3171-3181

[22] E. Anklam, S. Gaglione, A. Müller Oxidation behaviour of vanillin in dairy products Food Chem., 60 (1997), pp. 43-51

[23] J. Baumgartner, H. Neukom Enzymatische oxidation von vanillin Chimia (Aarau), 26 (1972), pp. 366-368

[24] S. Antoniotti, L. Santhanam, D. Ahuja, M.G. Hogg, J.S. Dordick Structural diversity of peroxidase-catalyzed oxidation products of o-methoxyphenols Org. Lett., 6 (2004), pp. 1975-1978

[25] R.T. Nishimura, C.H. Giammanco, D.A. Vosburg Green, enzymatic syntheses of divanillin and diapocynin for the organic, biochemistry, or advanced general chemistry laboratory J. Chem. Edu., 87 (2010), pp. 526-527

[26] H. Yoshida Chemistry of lacquer (Urushi) J. Chem. Soc. Trans., 43 (1883), pp. 472-486

[27] G. Benfield, S.M. Bocks, K. Bromley, B.R. Brown Studies of fungal and plant laccases Phytochemistry, 3 (1964), pp. $79-88$

[28] G. Diamantidis, A. Effosse, P. Potier, R. Bally Purification and characterization of the first bacterial laccase in the rhizospheric bacterium Azospirillum lipoferum Soil Biol. Biochem., 32 (2000), pp. 919-927

[29] J.M. Bollag, A. Leonowicz Comparative studies of extracellular fungal laccases Appl. Environ. Microbiol., 48 (1984), pp. 849-854

[30] M. Mogharabi, M.A. Faramarzi Laccase and laccase-mediated systems in the synthesis of organic compounds Adv. Synth. Catal., 356 (2014), pp. 897-927

[31] J.-R. Jeon, Y.-S. Chang Laccase-mediated oxidation of small organics: bifunctional roles for versatile applications Trends Biotechnol., 31 (2013), pp. 335-341

[32] S. Kobayashi, H. Uyama, S. Kimura Enzymatic polymerization Chem. Rev., 101 (2001), pp. 3793-3818

[33] S. Kobayashi, H. Higashimura Oxidative polymerization of phenols revisited Prog. Polym. Sci., 28 (2003), pp. 1015-1048

[34] S. Kobayashi, A. Makino Enzymatic polymer synthesis: an opportunity for green polymer chemistry Chem. Rev., 109 (2009), pp. 5288-5353

[35] N. Mita, H. Tawaki, S. Kobayashi Laccase-catalyzed oxidative polymerization of phenols Macromol. Biosci., 3 (2003), pp. 253-257

[36] S. Riva Laccases: blue enzymes for green chemistry Trends Biotechnol., 24 (2006), pp. 219-226

[37] E.I. Solomon, U.M. Sundaram, T.E. Machonkin Multicopper oxidases and oxygenases Chem. Rev., 96 (1996), pp. 2563-2606

[38] M.-A. Constantin, J. Conrad, U. Beifuss Laccase-catalyzed oxidative phenolic coupling of vanillidene derivatives Green Chem., 14 (2012), pp. 2375-2379

[39] S. Ncanana, L. Baratto, L. Roncaglia, S. Riva, S.G. Burton Laccase-mediated oxidation of totarol Adv. Synth. Catal., 349 (2007), pp. 1507-1513

[40] L. Baratto, A. Candido, M. Marzorati, F. Sagui, S. Riva, B. Danieli Laccase-mediated oxidation of natural glycosides J. Mol. Catal. B: Enzym., 39 (2006), pp. 3-8

[41] A. Intra, S. Nicotra, S. Riva, B. Danieli Significant and unexpected solvent influence on the selectivity of laccase-catalyzed coupling of tetrahydro-2-naphthol derivatives Adv. Synth. Catal., 347 (2005), pp. 973-977

[42] R. Ikeda, J. Sugihara, H. Uyama, S. Kobayashi Enzymatic oxidative polymerization of 4-hydroxybenzoic acid derivatives to poly(phenylene oxide)s Polym. Int., 47 (1998), pp. 295-301

[43] M. Lahtinen, K. Kruus, P. Heinonen, J. Sipilä On the reactions of two fungal laccases differing in their redox potential with lignin model compounds: products and their rate of formation J. Agric. Food Chem., 57 (2009), pp. 8357-8365

[44] H.P. Lahtinen M, M. Oivanen, P. Karhunen, K. Kruus, J. Sipilä On the factors affecting product distribution in laccase-catalyzed oxidation of a lignin model compound vanillyl alcohol: experimental and computational evaluation Org. Biomol. Chem., 11 (2013), pp. 5454-5464

[45] C. Ponzoni, E. Beneventi, M.R. Cramarossa, S. Raimondi, G. Trevisi, U.M. Pagnoni, S. Riva, L. Forti Laccasecatalyzed dimerization of hydroxystilbenes Adv. Synth. Catal., 349 (2007), pp. 1497-1506

[46] A. Aljawish, I. Chevalot, J. Jasniewski, C. Paris, J. Scher, L. Muniglia Laccase-catalysed oxidation of ferulic acid and ethyl ferulate in aqueous medium: a green procedure for the synthesis of new compounds Food Chem., 145 (2014), pp. 1046-1054

[47] O.E. Adelakun, T. Kudanga, A. Parker, I.R. Green, M. le Roes-Hill, S.G. Burton Laccase-catalyzed dimerization of ferulic acid amplifies antioxidant activity J. Mol. Catal. B: Enzym., 74 (2012), pp. 29-35 
[48] C. Navarra, P. Gavezzotti, D. Monti, W. Panzeri, S. Riva Biocatalyzed synthesis of enantiomerically enriched $\beta$-5-like dimer of 4-vinylphenol J. Mol. Catal. B: Enzym., 84 (2012), pp. 115-120

[49] O.E. Adelakun, T. Kudanga, I.R. Green, M. le Roes-Hill, S.G. Burton Enzymatic modification of 2,6dimethoxyphenol for the synthesis of dimers with high antioxidant capacity Process Biochem., 47 (2012), pp. 1926-1932

[50] A. Martorana, R. Vazquez-Duhalt, S.A. Aguila, R. Basosi, M.C. Baratto Spectroscopic characterization of 2,6dimethoxyphenol radical intermediates in the Coriolopsis gallica laccase-mediator system J. Mol. Catal. B: Enzym., 107 (2014), pp. 100-105

[51] C. Bohlin, K. Lundquist, L.J. Jönsson Oxidation of the erythro and threo forms of the phenolic lignin model compound 1-(4-hydroxy-3-methoxyphenyl)-2-(2-methoxyphenoxy)-1,3-propanediol by laccases and model oxidants Bioorg. Chem., 37 (2009), pp. 143-148 


\title{
Supporting Information: Highly selective laccase-catalyzed
}

dimerization of phenolic compounds derived from lignin: towards original symmetrical bio-based (bis)aromatic monomers

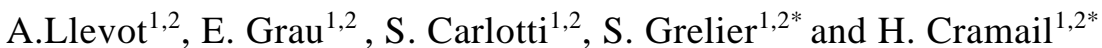

(a)

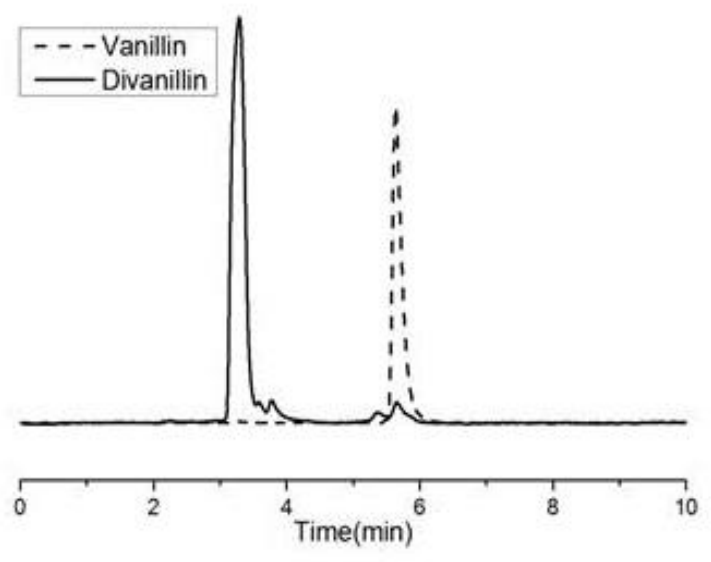

(b)

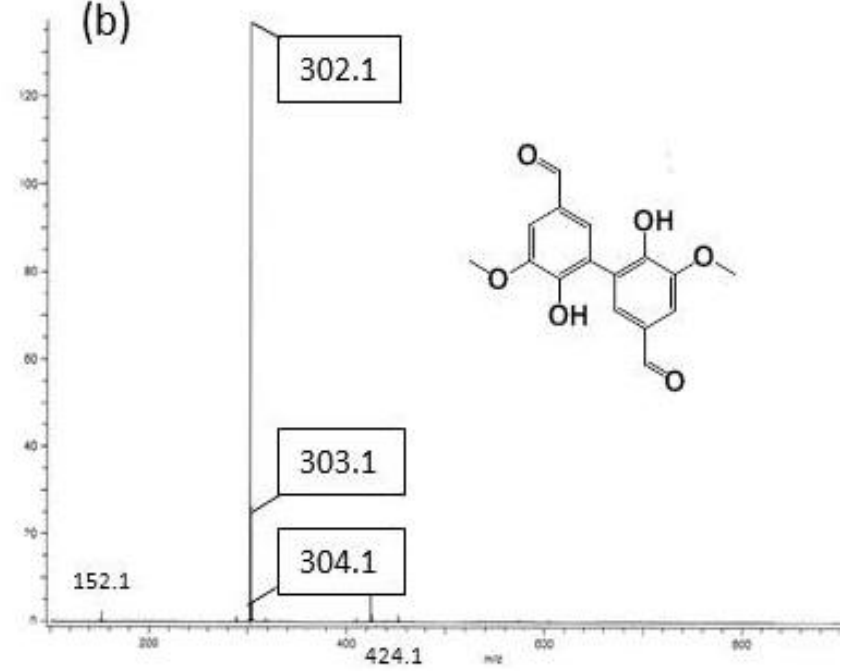

Figure S1: HPLC profile of vanillin (dashed line) and divanillin (straight line), using a C18 grafted silica column in acetonitrile with a UV detector (a), Mass spectrum of divanillin ionized by electronic impact positive mode, direct introduction (b). 


\section{Vanillin}

志

윢 용

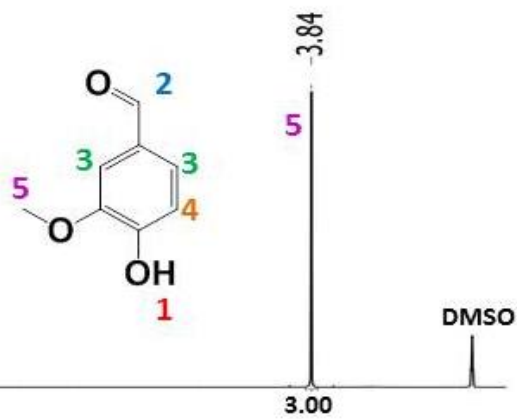

Divanillin

क्ष

용 占

ఇু চ্ল

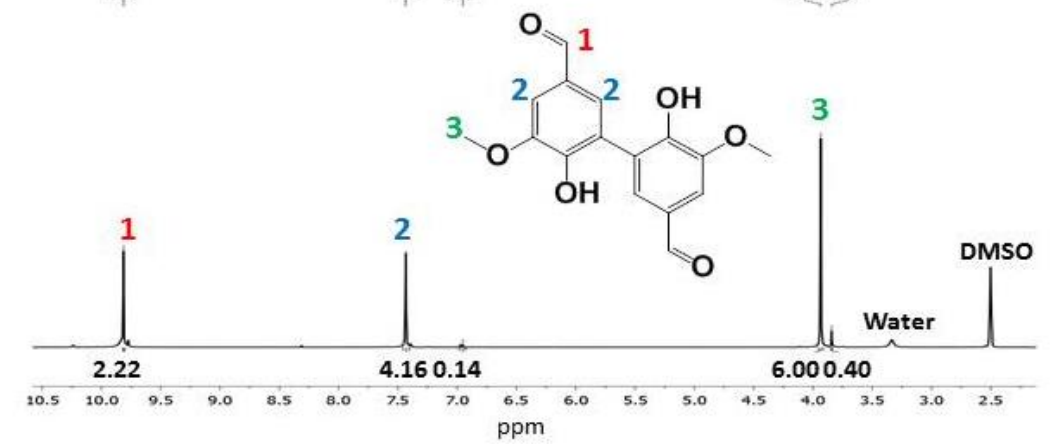

Figure S2: ${ }^{1} \mathrm{H}$ NMR spectra of vanillin (top) and divanillin (bottom) in DMSO at room temperature.

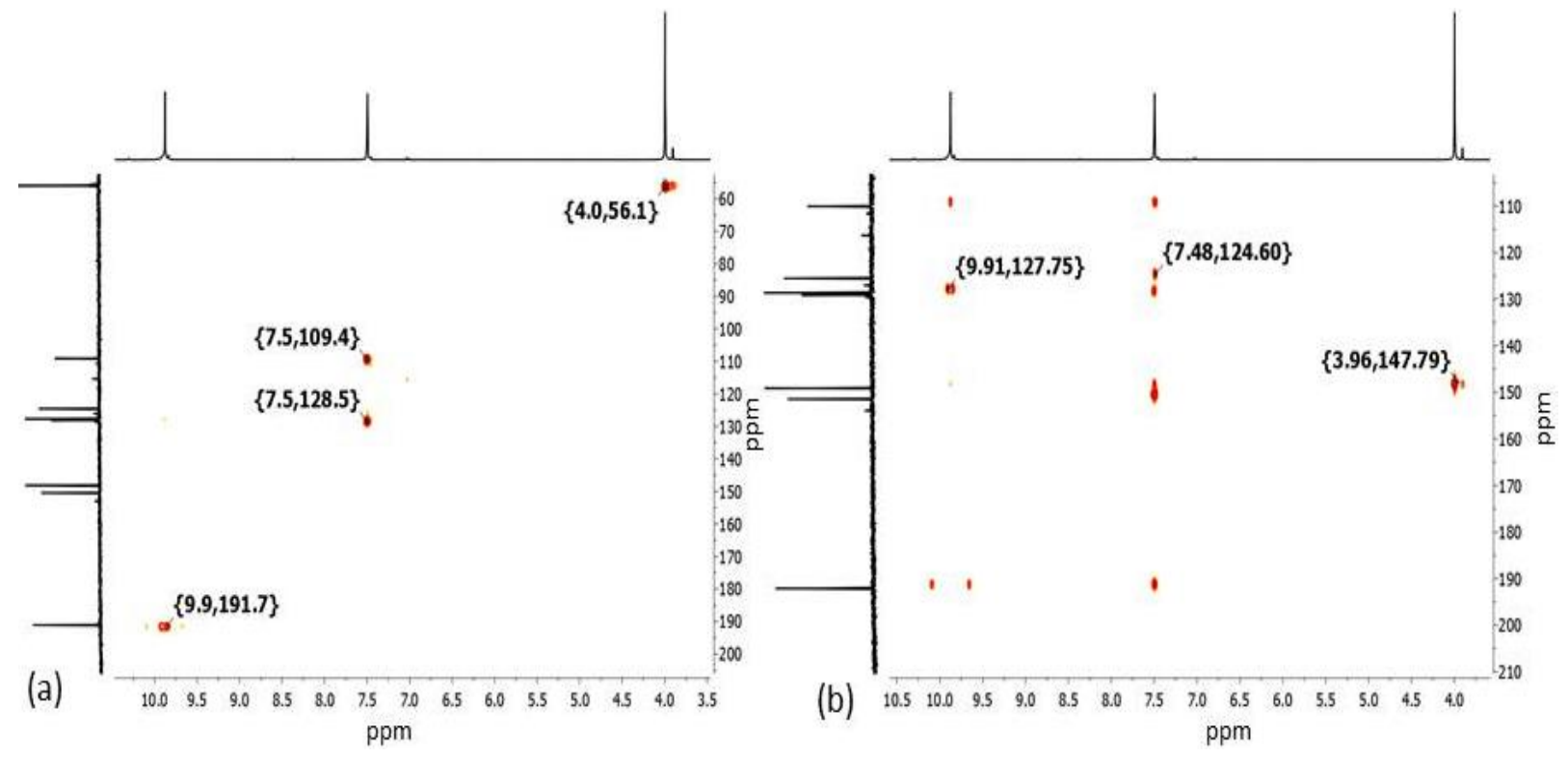

Figure S3: HSQC (a) and HMBC (b) spectra of divanillin in DMSO, at room temperature. 


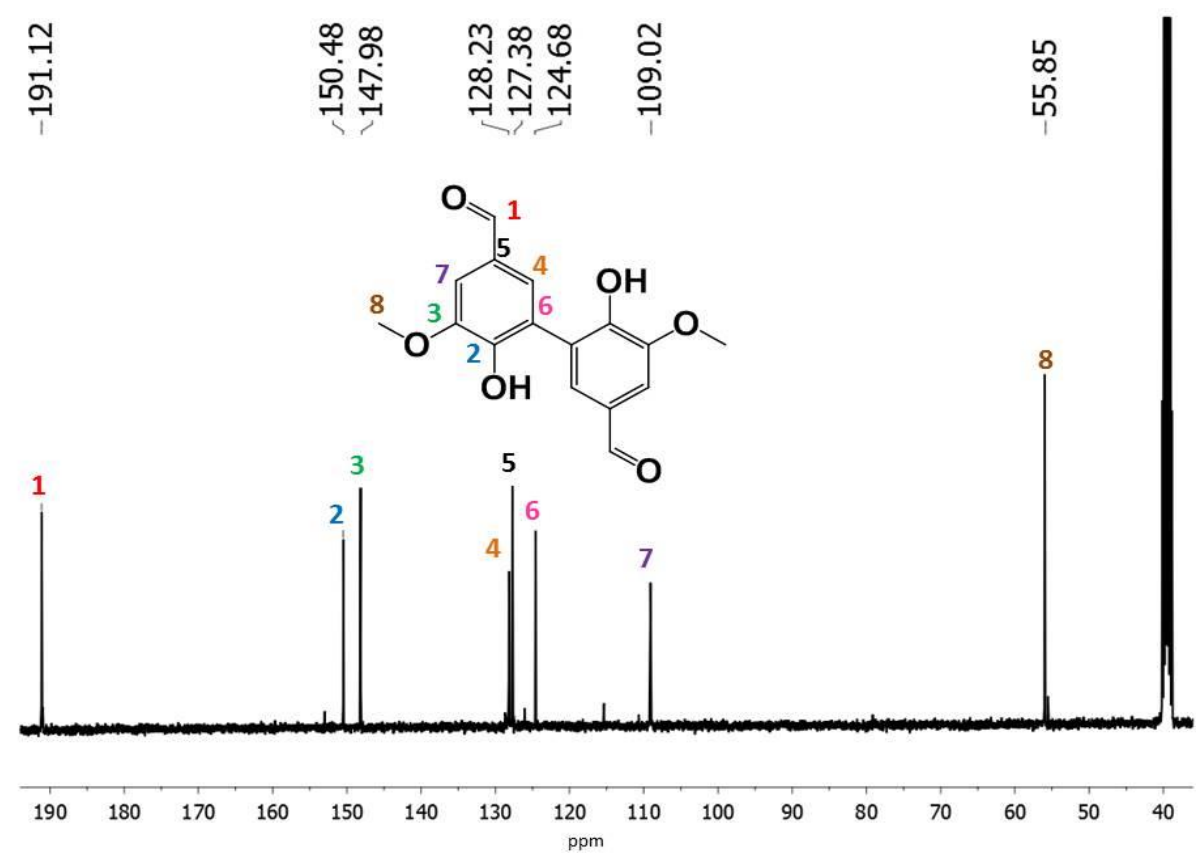

Figure S4: ${ }^{13} \mathrm{C}$ NMR spectrum of divanillin in DMSO, at room temperature.

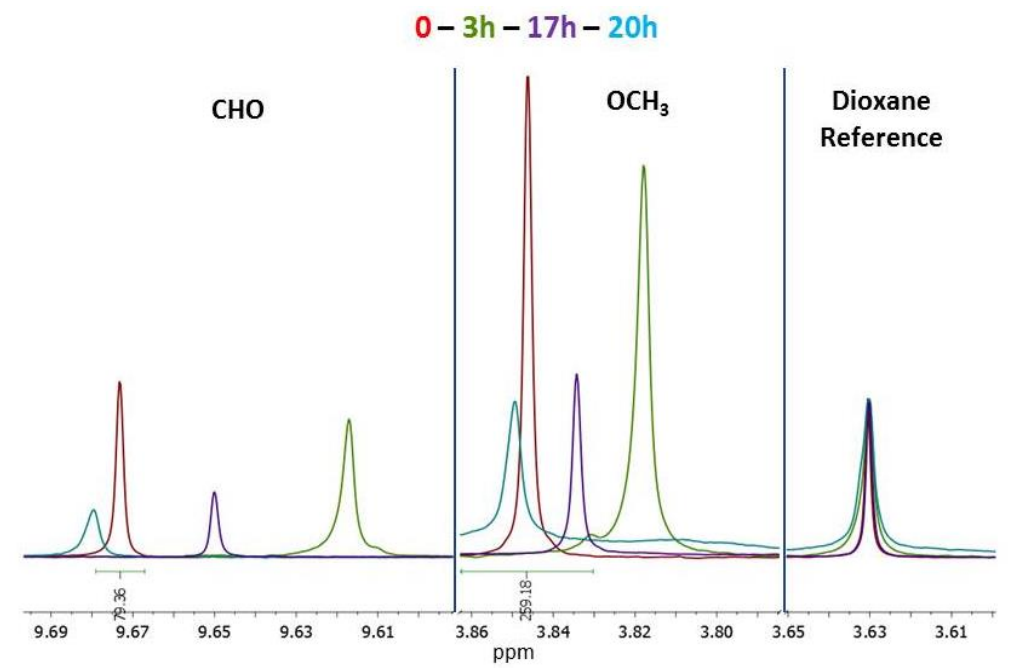

Figure S5: ${ }^{1} \mathrm{H}$ NMR spectra of remaining vanillin in solution during dimerization initial (red), after $3 \mathrm{~h}$ (green), after $17 \mathrm{~h}$ (purple), after $20 \mathrm{~h}$ (blue). 


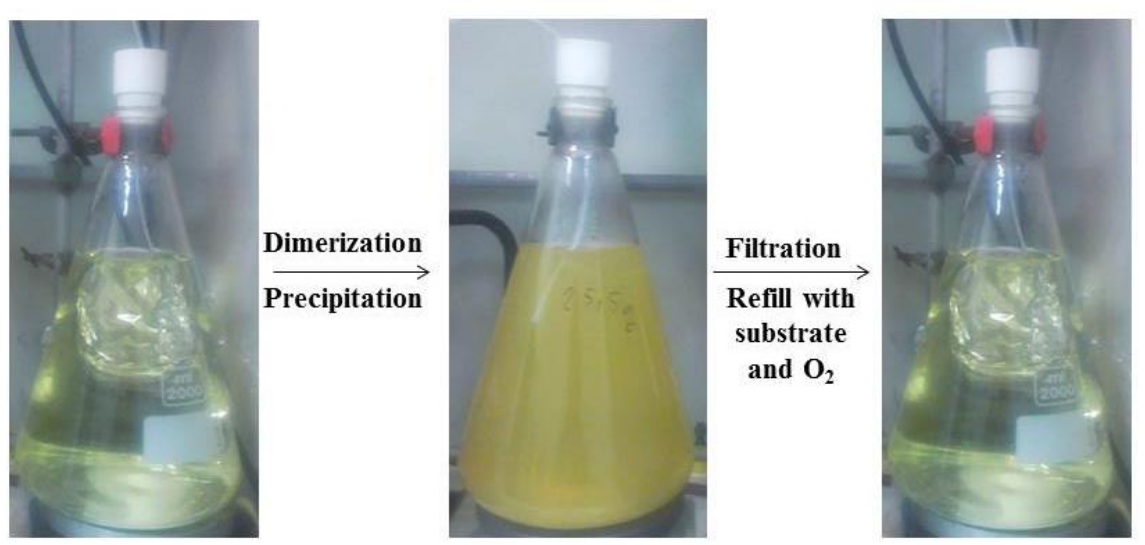

Figure S6: Process of vanillin dimerization: precipitation, filtration, refill.

(a)<smiles>COc1cc(C(=O)O)ccc1O</smiles>

Vanillic acid

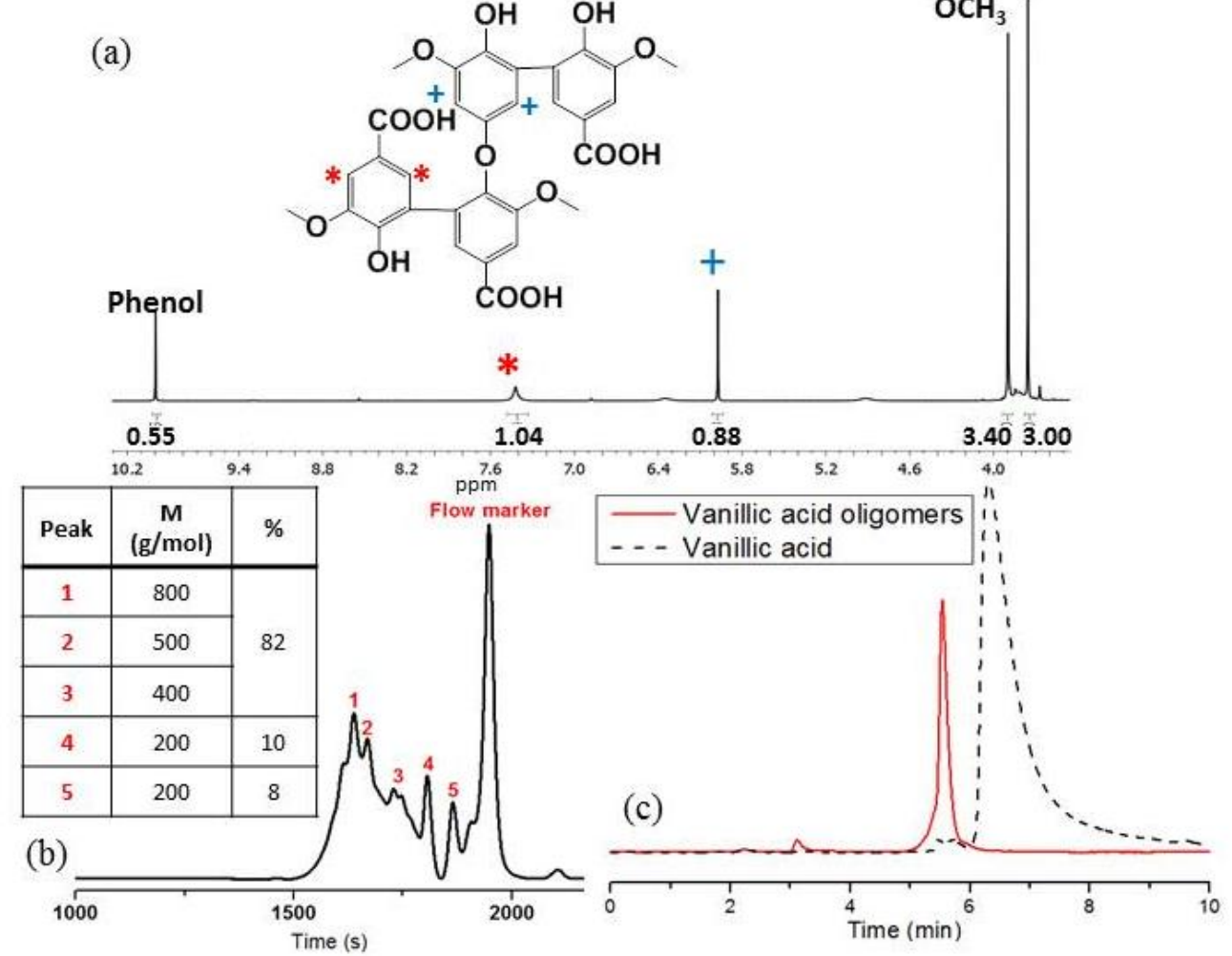

Figure S7: ${ }^{1} \mathrm{H}$ NMR spectrum in DMSO at room temperature (a), SEC trace in THF (b), HPLC profile using a C18 grafted silica column and acetonitrile as eluent (c) of product obtained by coupling of vanillic acid catalyzed by laccase. 


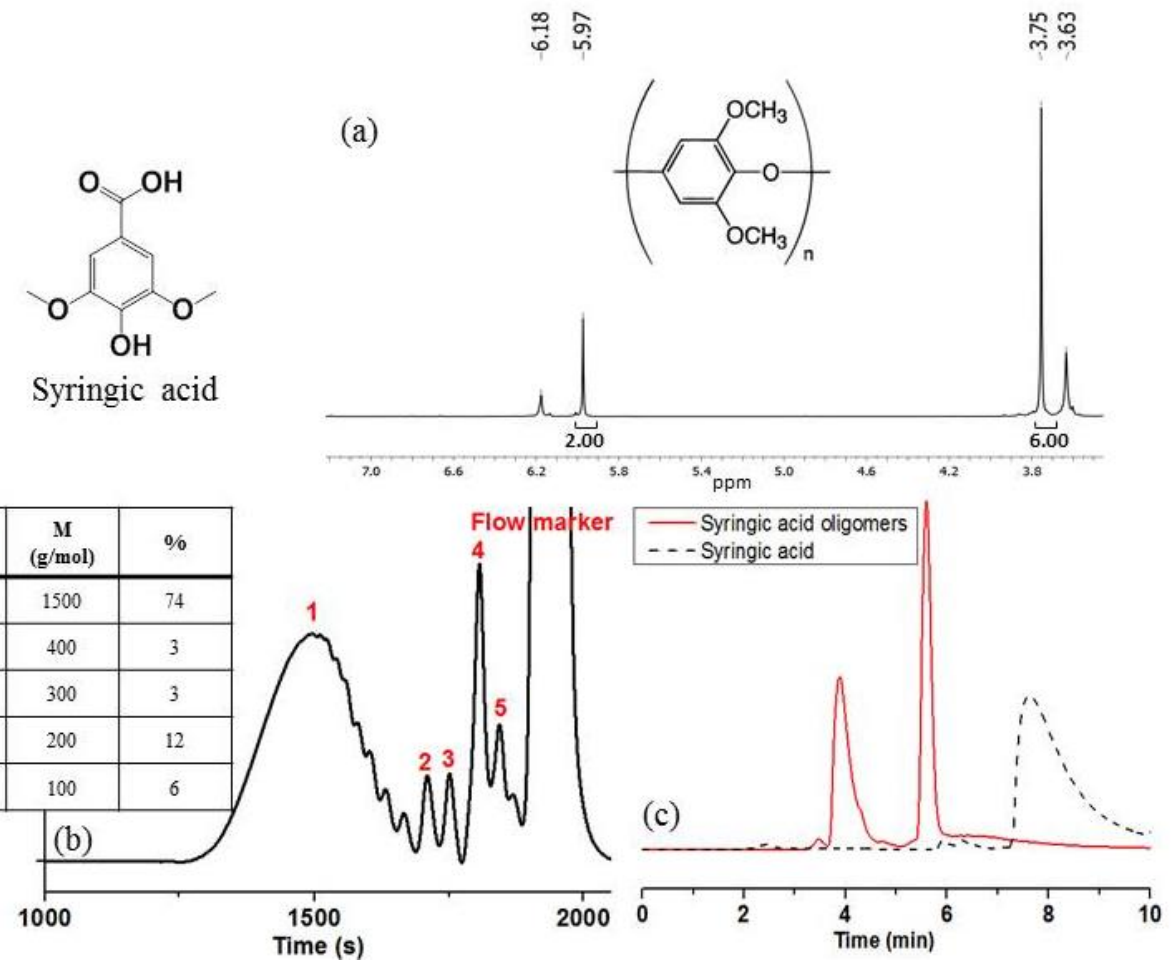

Figure S8: ${ }^{1} \mathrm{H}$ NMR spectrum in DMSO at room temperature (a), SEC trace in THF (b), HPLC profile using a C18 grafted silica column and acetonitrile as eluent (c) of product obtained by coupling of syringic acid catalyzed by laccase.

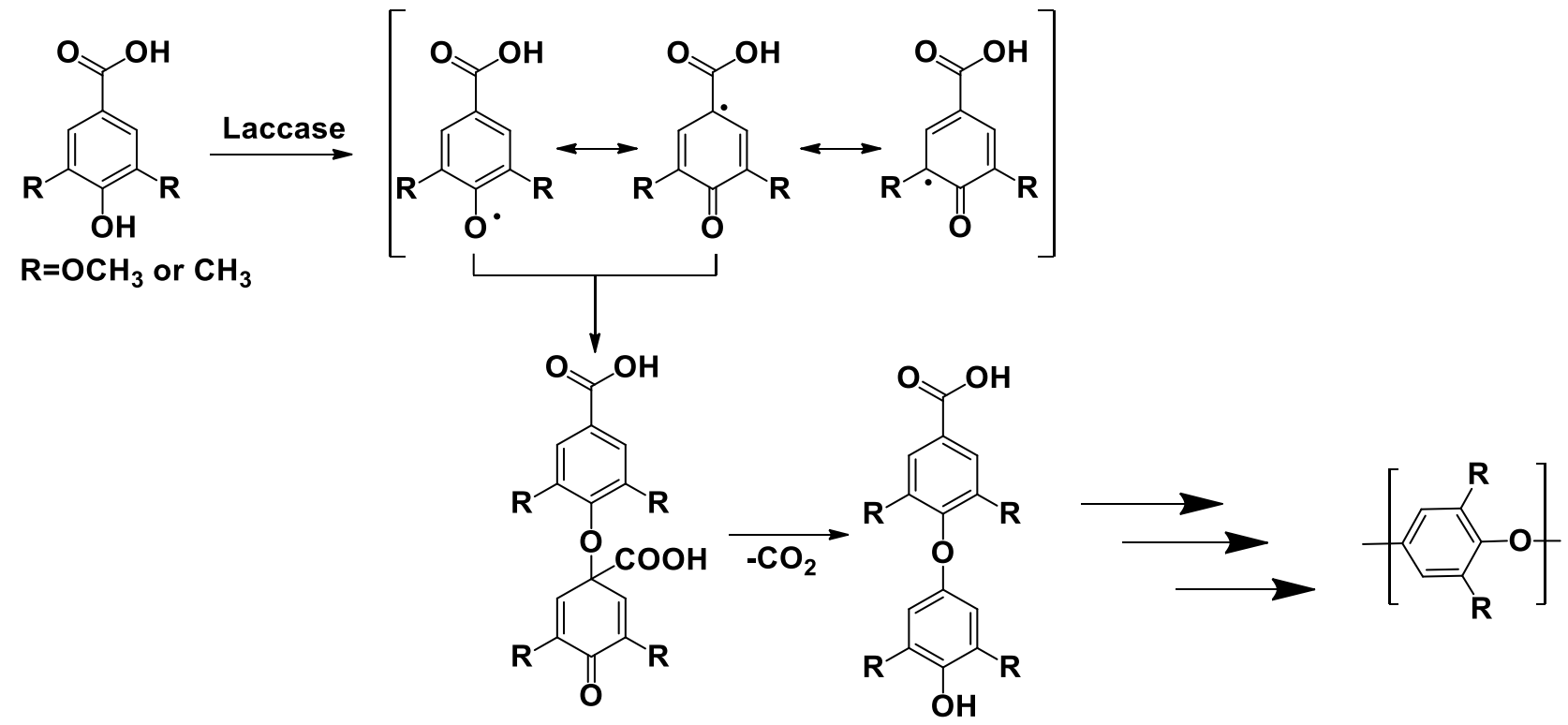

Figure S9: Proposed mechanism for decarboxylation of ortho-substituted 4-hydroxybenzoic acid derivatives catalyzed by laccase. 


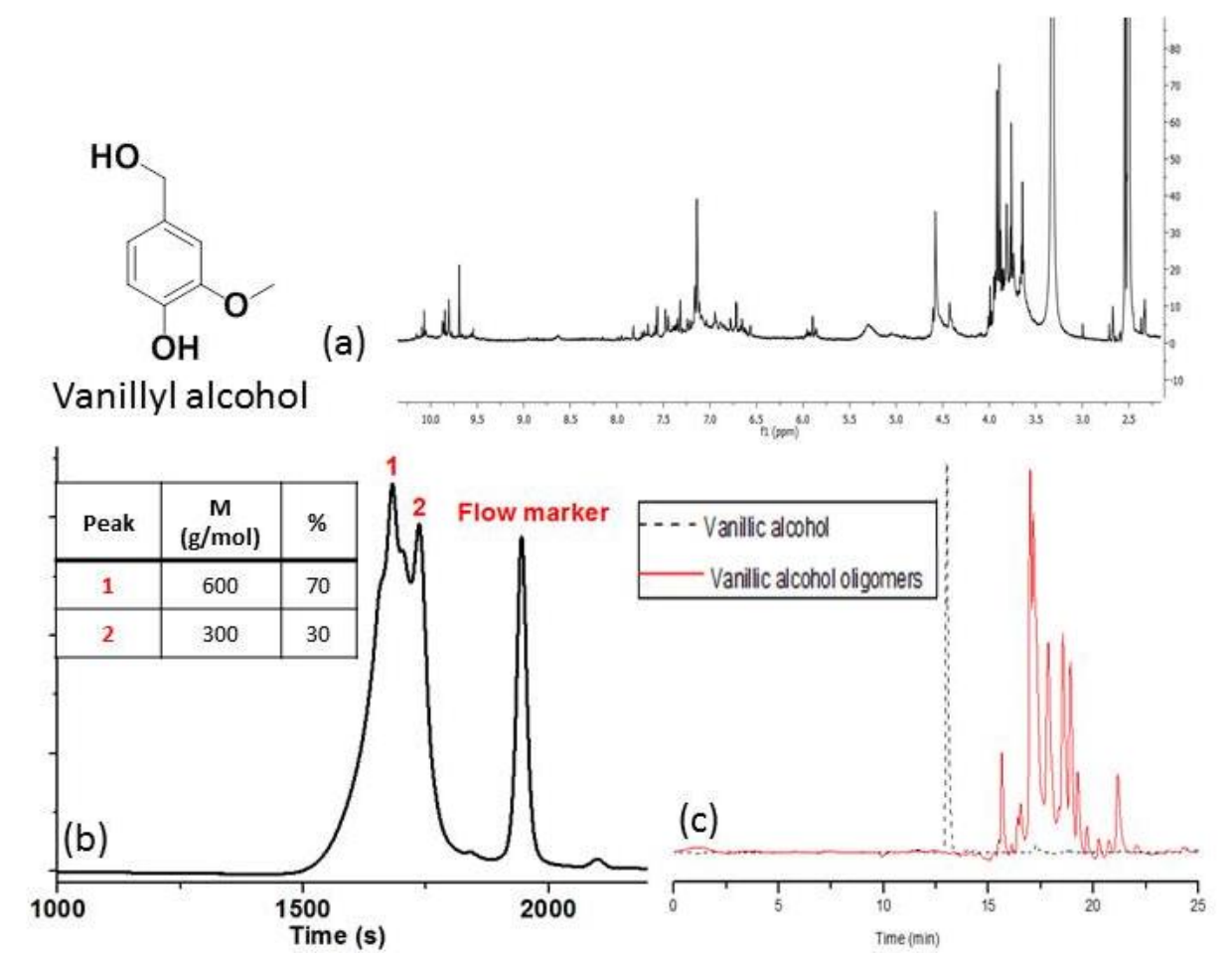

Figure S10: ${ }^{1} \mathrm{H}$ NMR spectrum in DMSO at room temperature (a), SEC trace in THF (b), HPLC profile using a C18 grafted silica column and acetonitrile as eluent (c) of the product obtained by vanillyl alcohol coupling catalyzed by laccase.

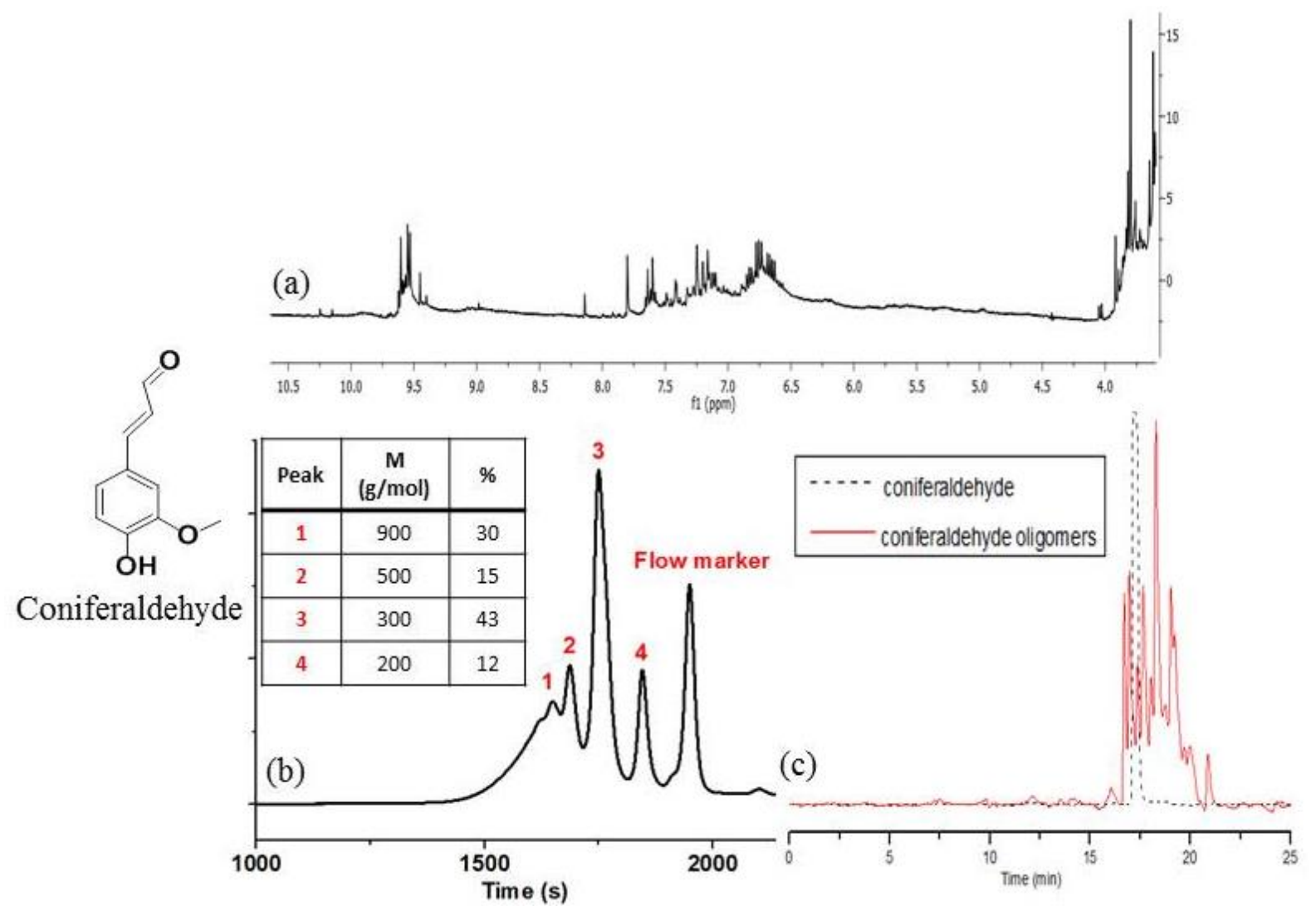

Figure S11: (a) ${ }^{1} \mathrm{H}$ NMR spectrum in DMSO at room temperature, (b) SEC trace in THF, (c) HPLC profile using a $\mathrm{C} 18$ grafted silica column and acetonitrile as eluent of product obtained by coniferaldehyde coupling catalyzed by laccase 


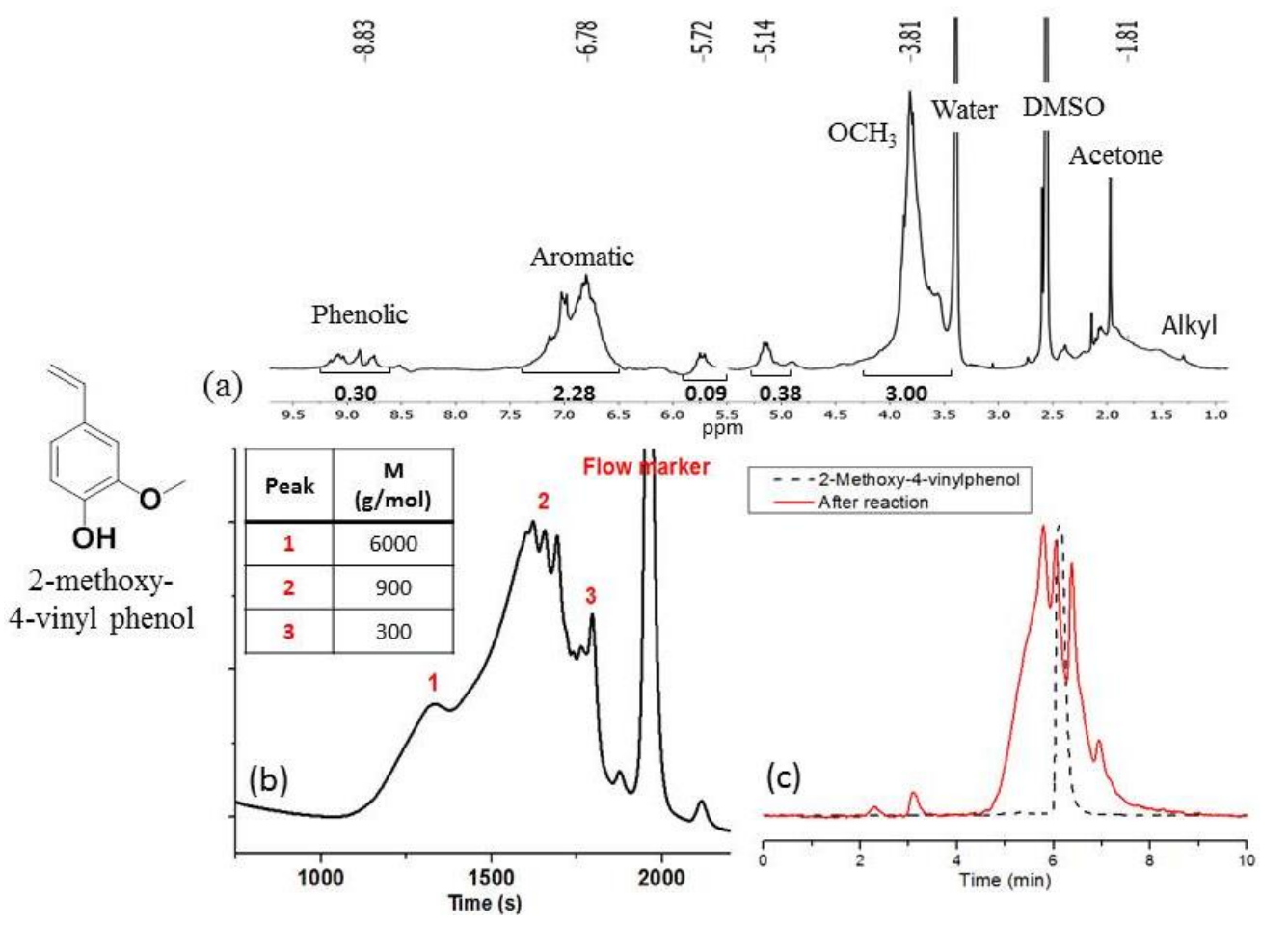

Figure S12: ${ }^{1} \mathrm{H}$ NMR spectrum in DMSO at room temperature (a), SEC trace in THF (b), HPLC profile using a C18 grafted silica column and acetonitrile as eluent (c) of products resulting from 2-methoxy-4vinylphenol coupling catalyzed by laccase. 


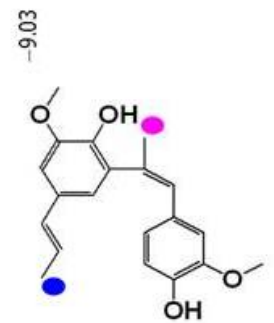

D5

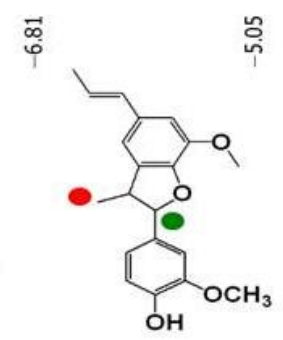

D3
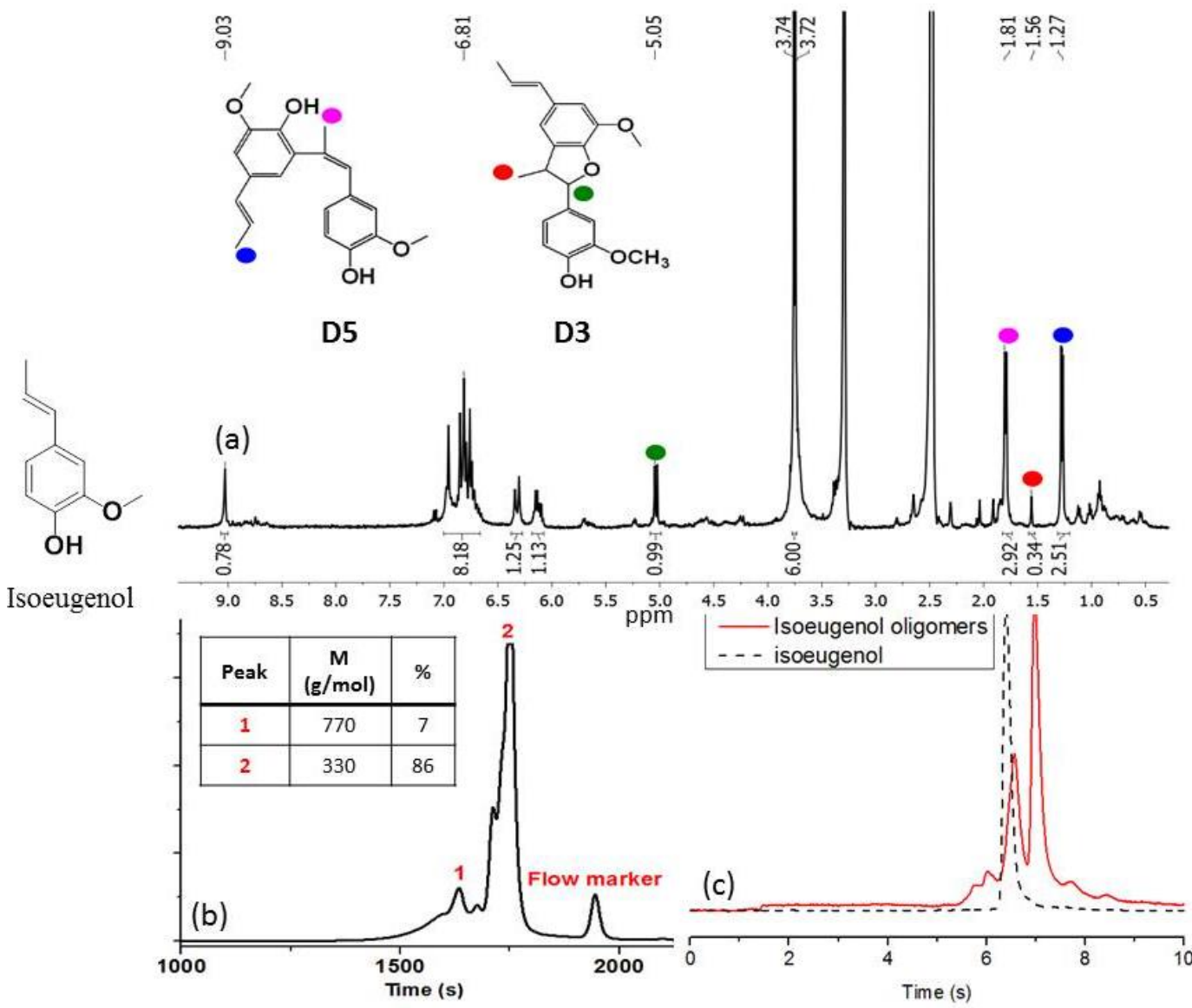

Figure S13: ${ }^{1} \mathrm{H}$ NMR spectrum in DMSO at room temperature (a), SEC trace in THF (b), HPLC profile using a C18 grafted silica column and acetonitrile as eluent (c) of the product obtained by coupling of isoeugenol catalyzed by laccase. 


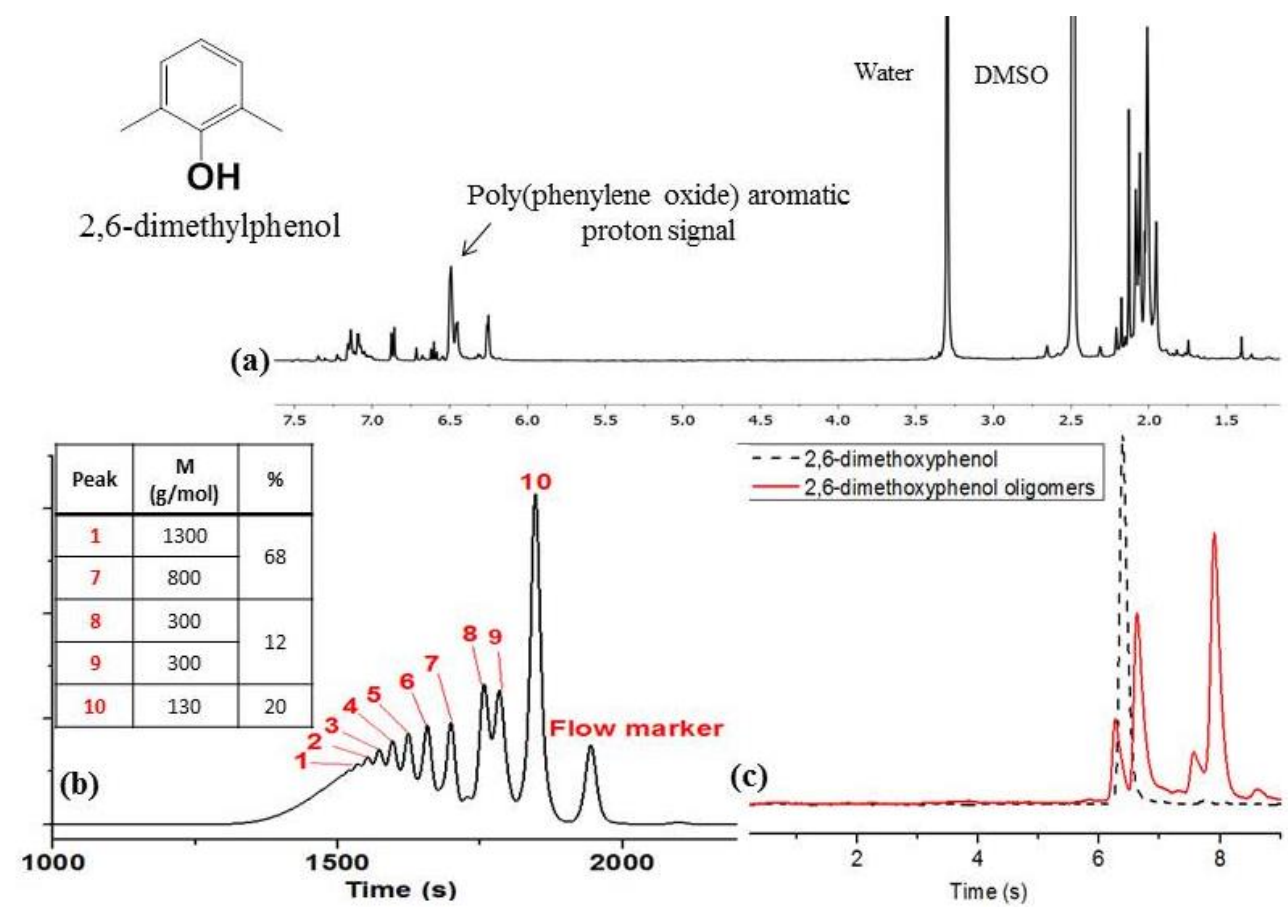

Figure S24: ${ }^{1} \mathrm{H}$ NMR spectrum in DMSO at room temperature (a), SEC trace in THF (b), HPLC profile using a C18 grafted silica column and acetonitrile as eluent (c) of product obtained by 2,6-dimethylphenol coupling catalyzed by laccase. 


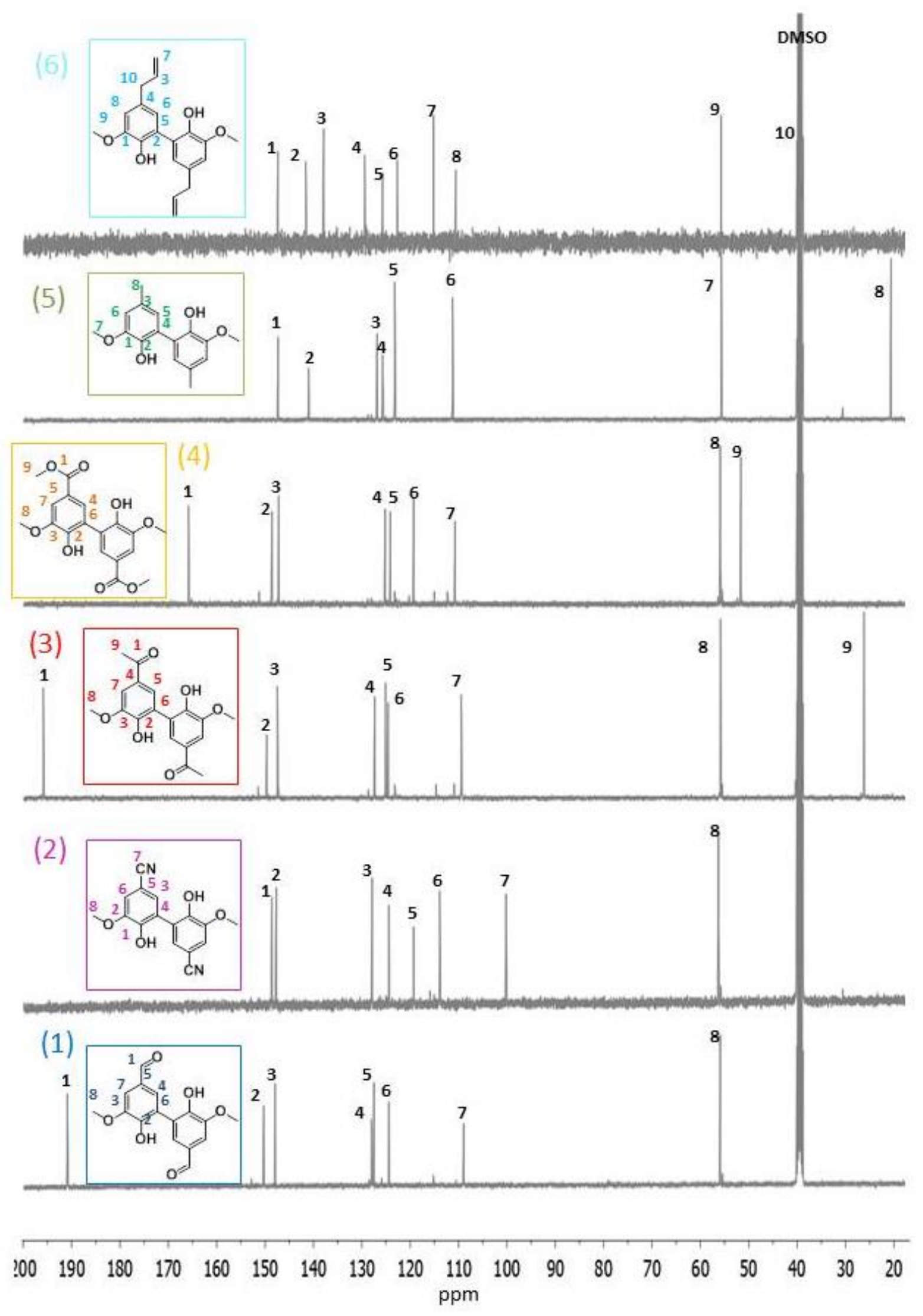

Figure S35: ${ }^{13} \mathrm{C}$ NMR spectra of the dimers obtained by selective oxidative coupling catalyzed by laccase. 


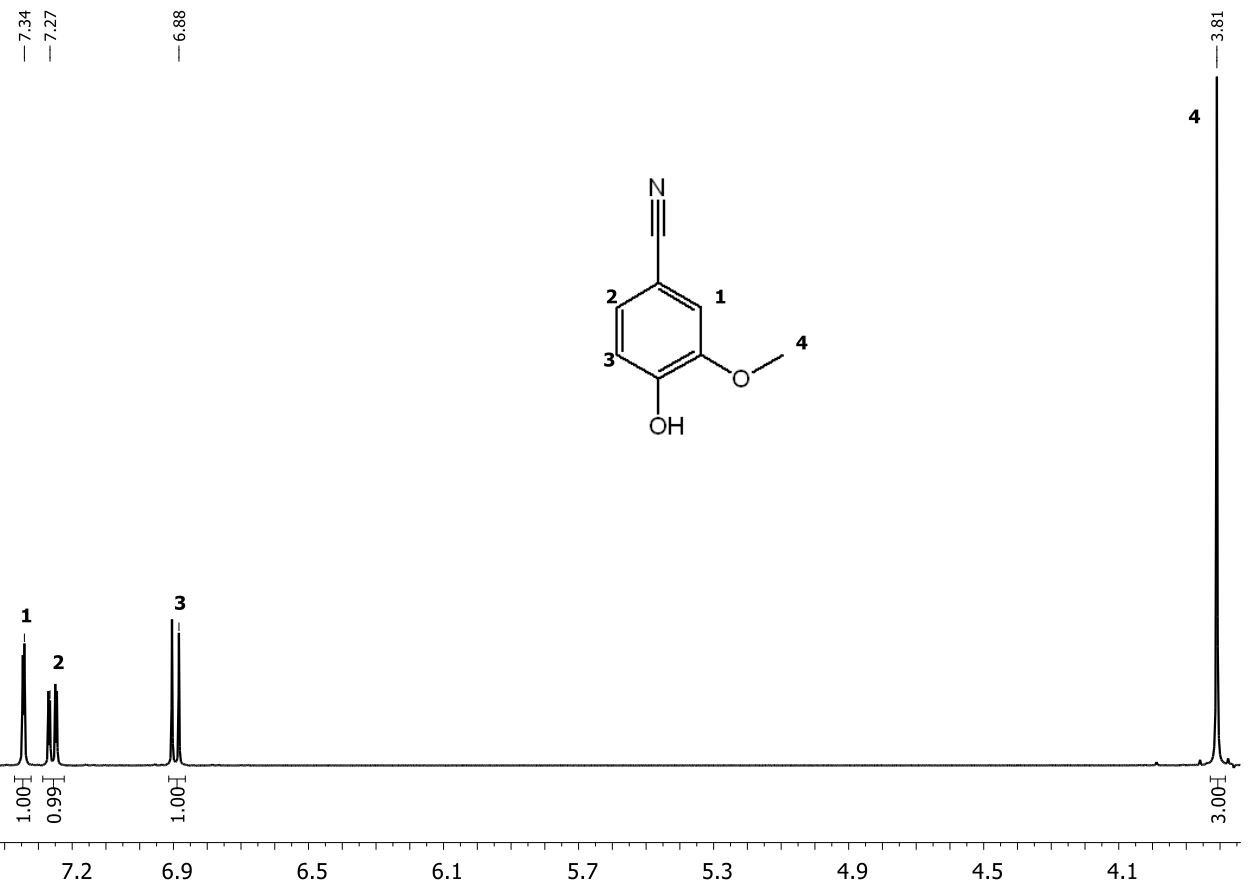

Figure S46: ${ }^{1} \mathrm{H}$ NMR spectrum of 4-hydroxy3-methoxyvenzonitrile in DMSO, at room temperature.
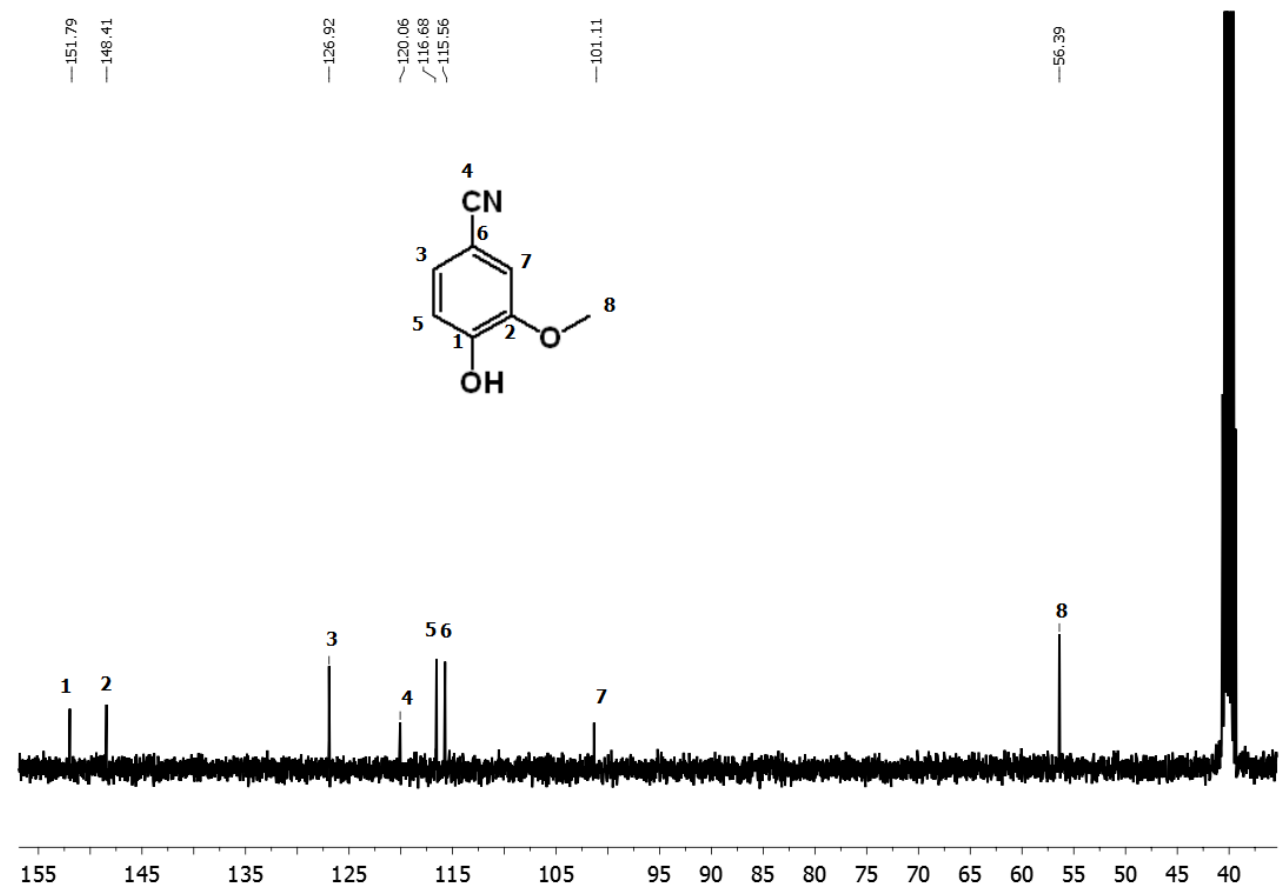

Figure S57: ${ }^{13} \mathrm{C}$ NMR spectrum of 4-hydroxy3-methoxyvenzonitrile in DMSO, at room temperature. 

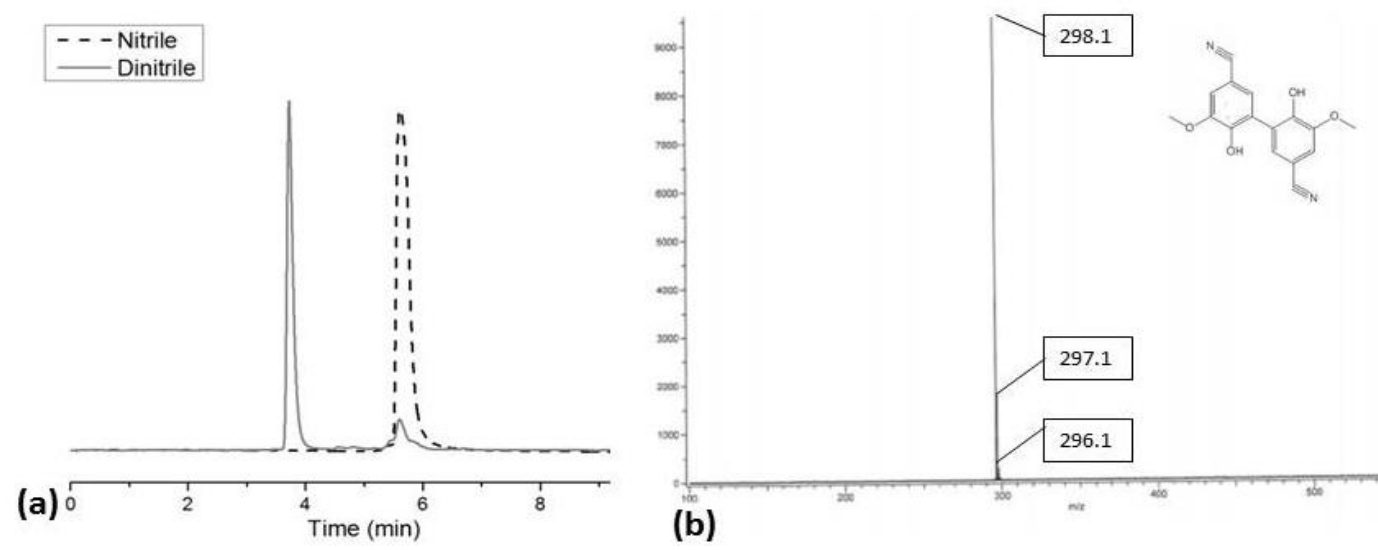

(b)

Figure S68: (a) HPLC profile of 4-hydroxy3-methoxyvenzonitrile (dashed line) and 4-hydroxy3methoxyvenzonitrile dimer (2) (straight line), using a C18 grafted silica column in acetonitrile with a UV detector, (b) Mass spectrum of 4-hydroxy3-methoxyvenzonitrile (2) ionized by electronic impact,positive mode, direct introduction.

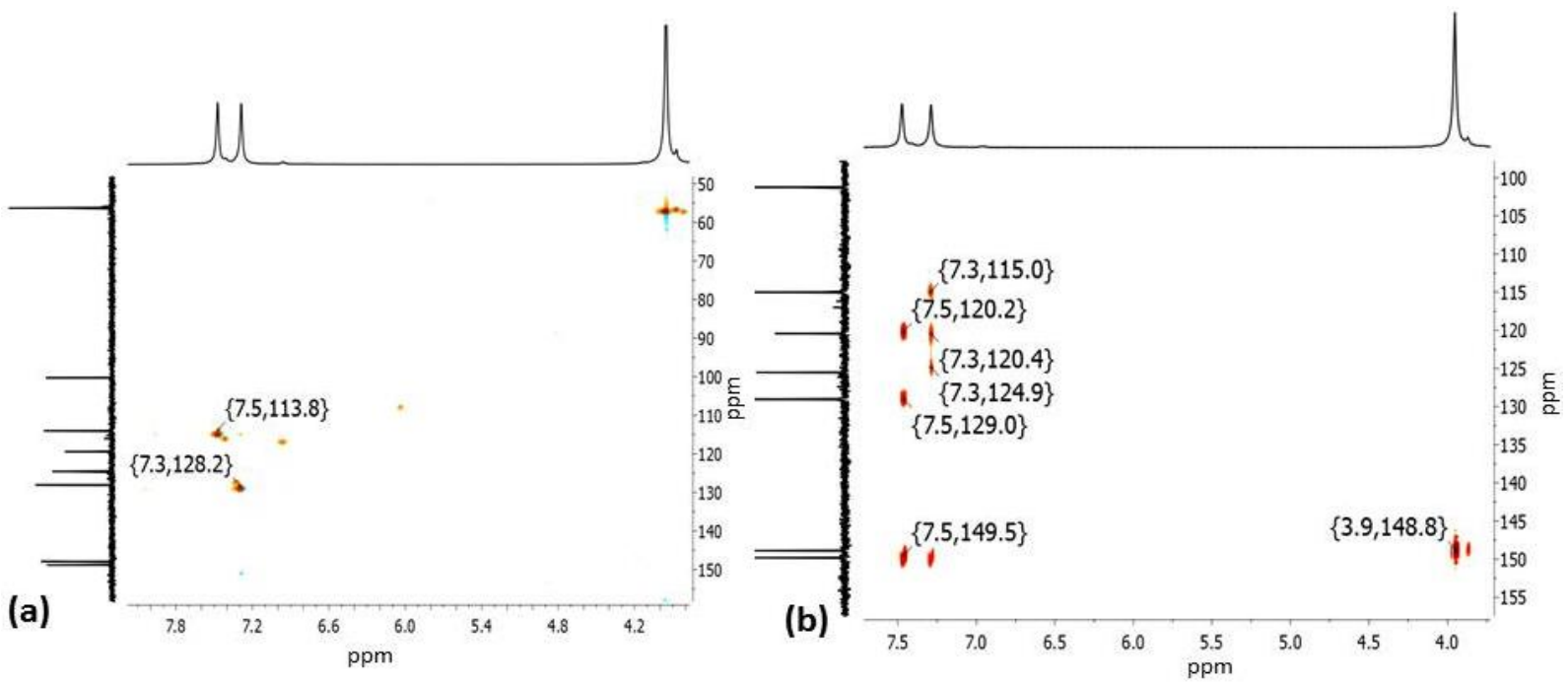

Figure S79: HSQC (a) and HMBC (b) spectra of 4-hydroxy3-methoxybenzonitrile (2) in DMSO, at room temperature.

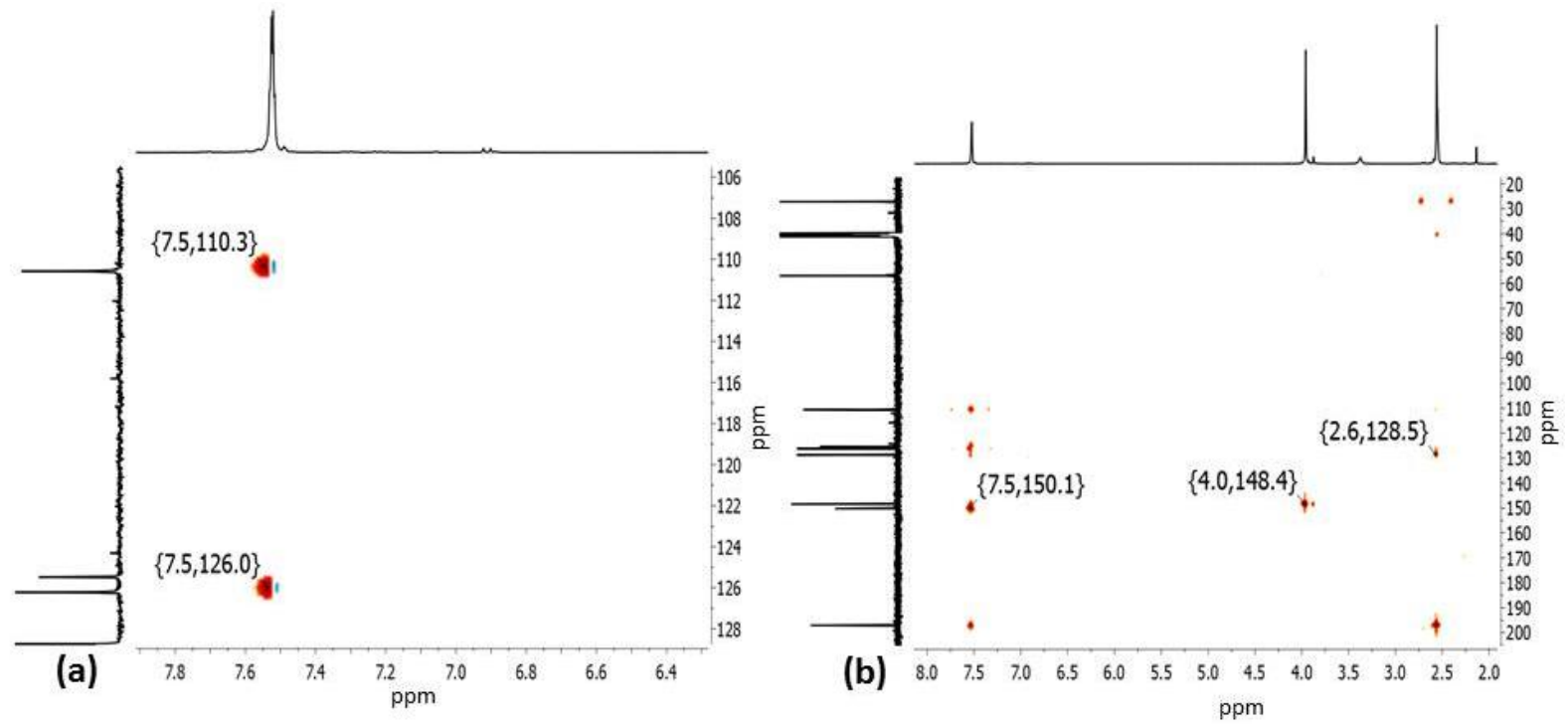

Figure S208: HSQC (zoom on the aromatic region) (a) and HMBC (b) spectra of acetovanillon dimer (3) in DMSO, at room temperature. 
$\stackrel{\substack{7 \\ i}}{\substack{0 \\ 0}}$<smiles>COC(=O)c1ccc(O)c(OC)c1</smiles>

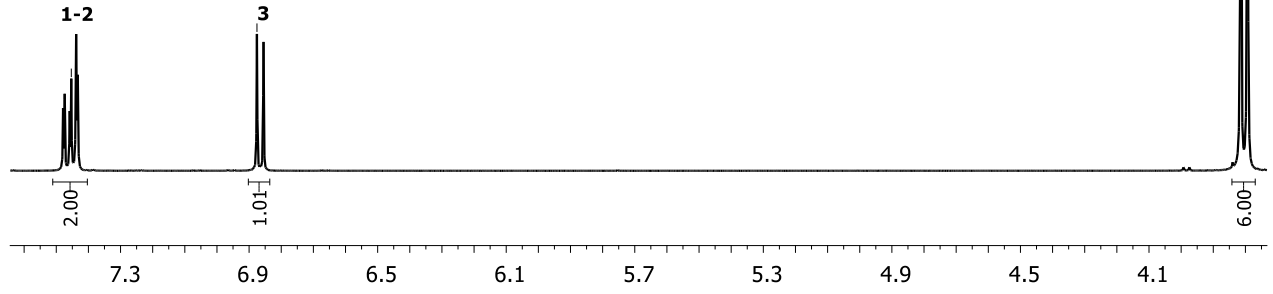

Figure S91: ${ }^{1} \mathrm{H}$ NMR spectrum of methyl vanillate in DMSO, at room temperature.

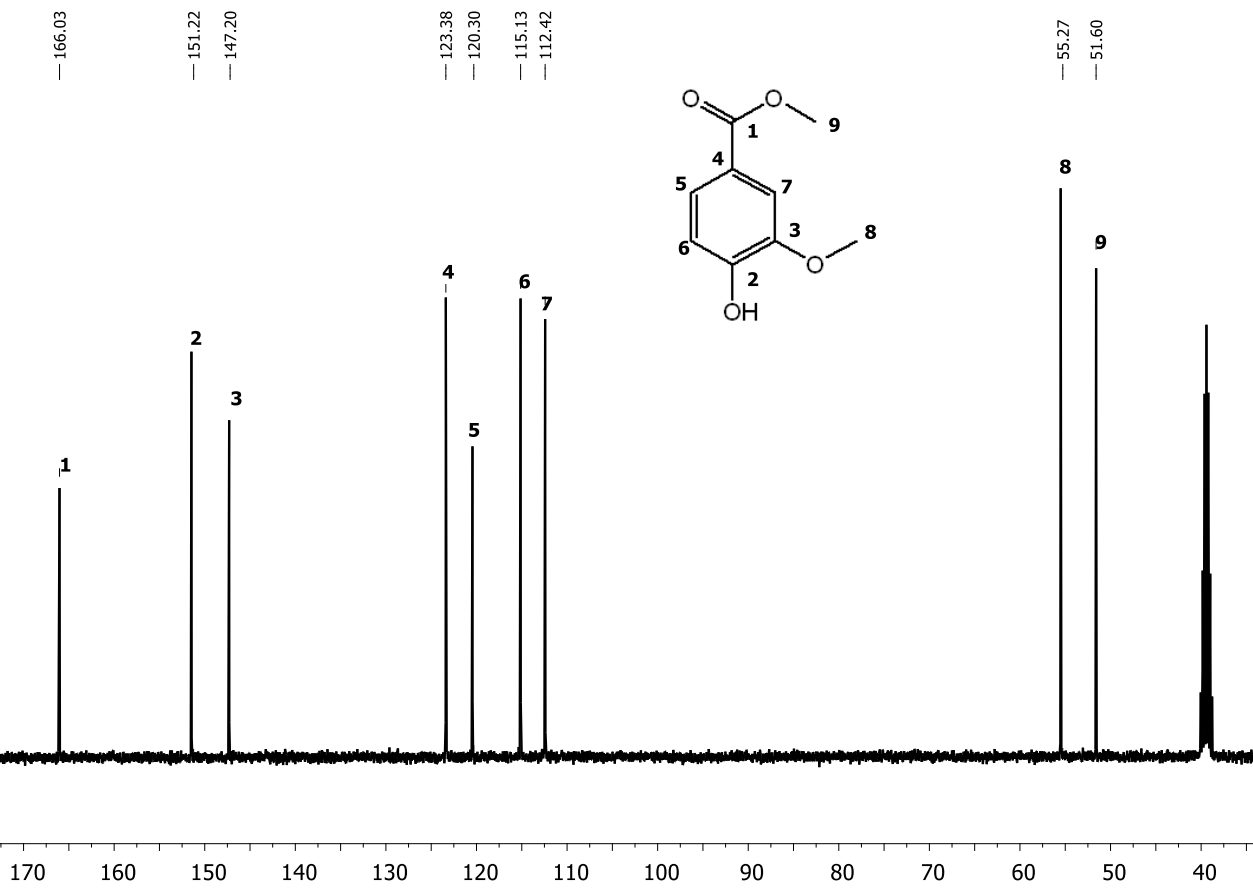

Figure S102: ${ }^{13} \mathrm{C}$ NMR spectrum of methyl vanillate in DMSO, at room temperature. 


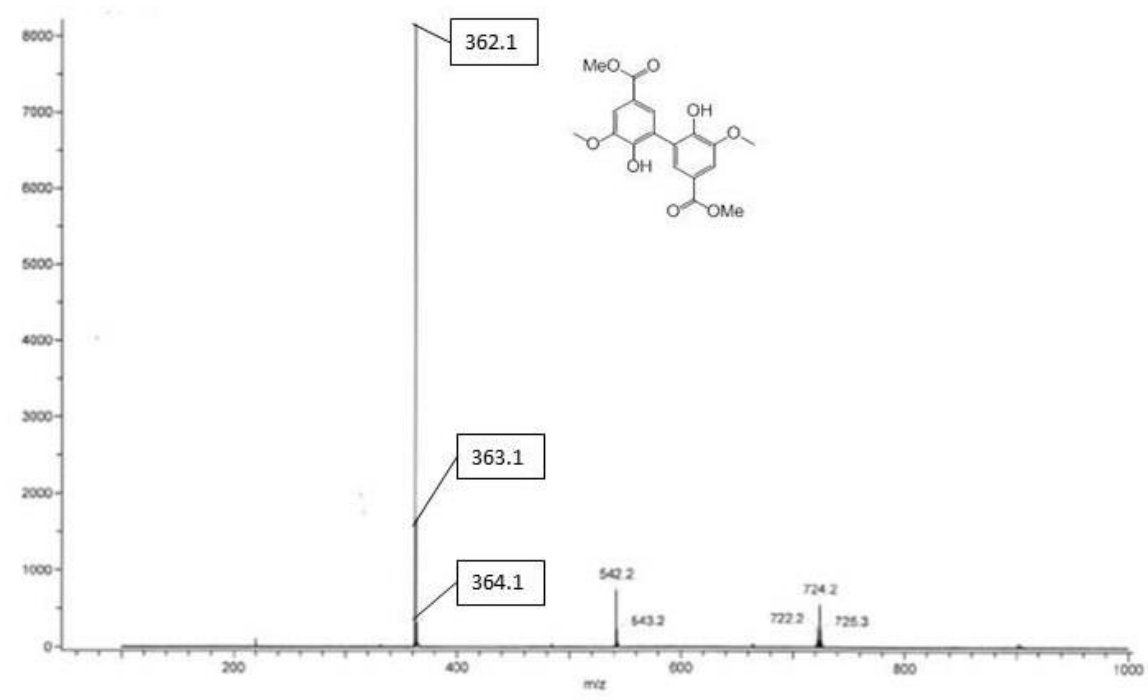

Figure S113: Mass spectrum of methyl vanillate dimer (4) ionized by electronic impact, positive mode, direct introduction.

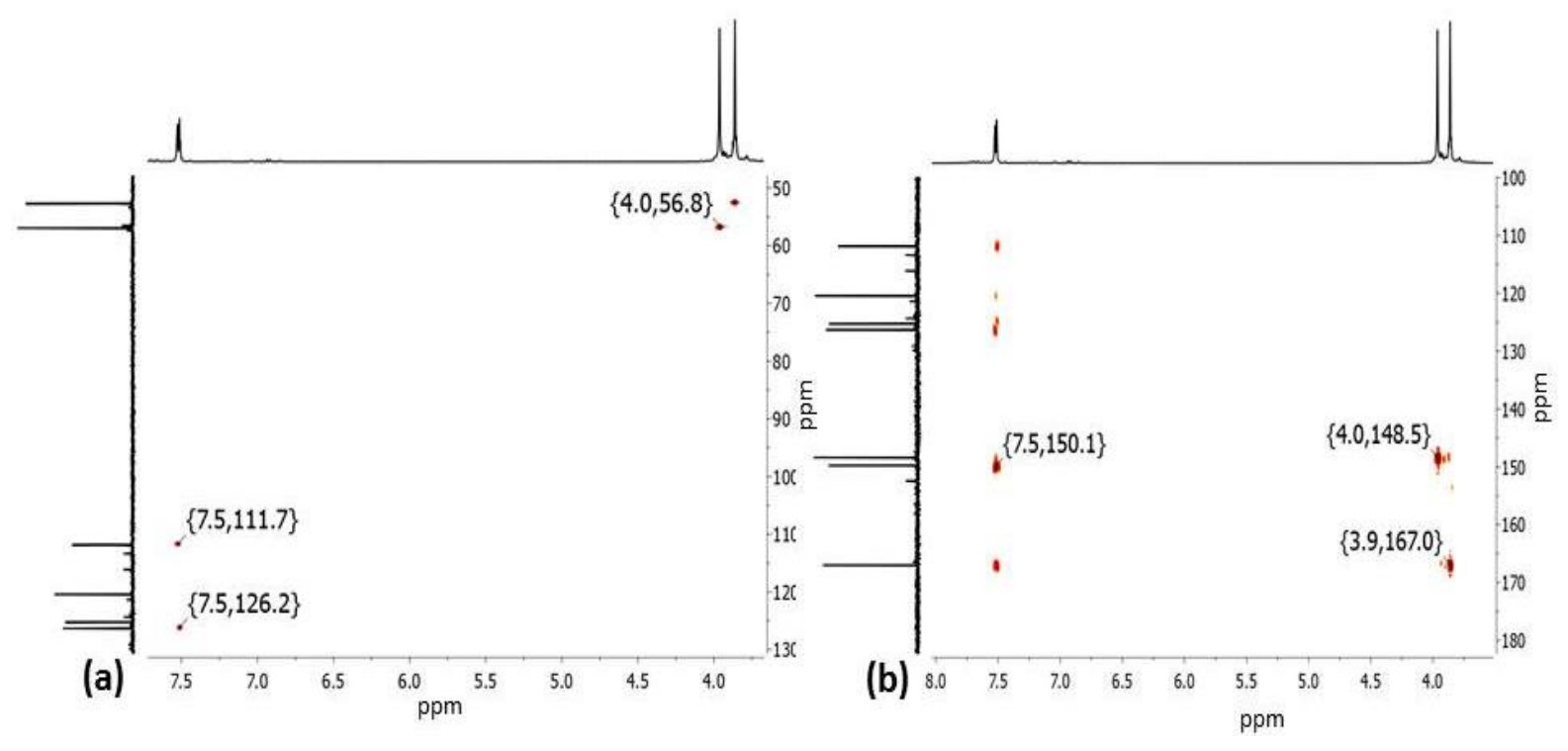

Figure S124: HSQC (a) and HMBC (b) spectra of methyl vanillate dimer (4) in DMSO, at room temperature. 

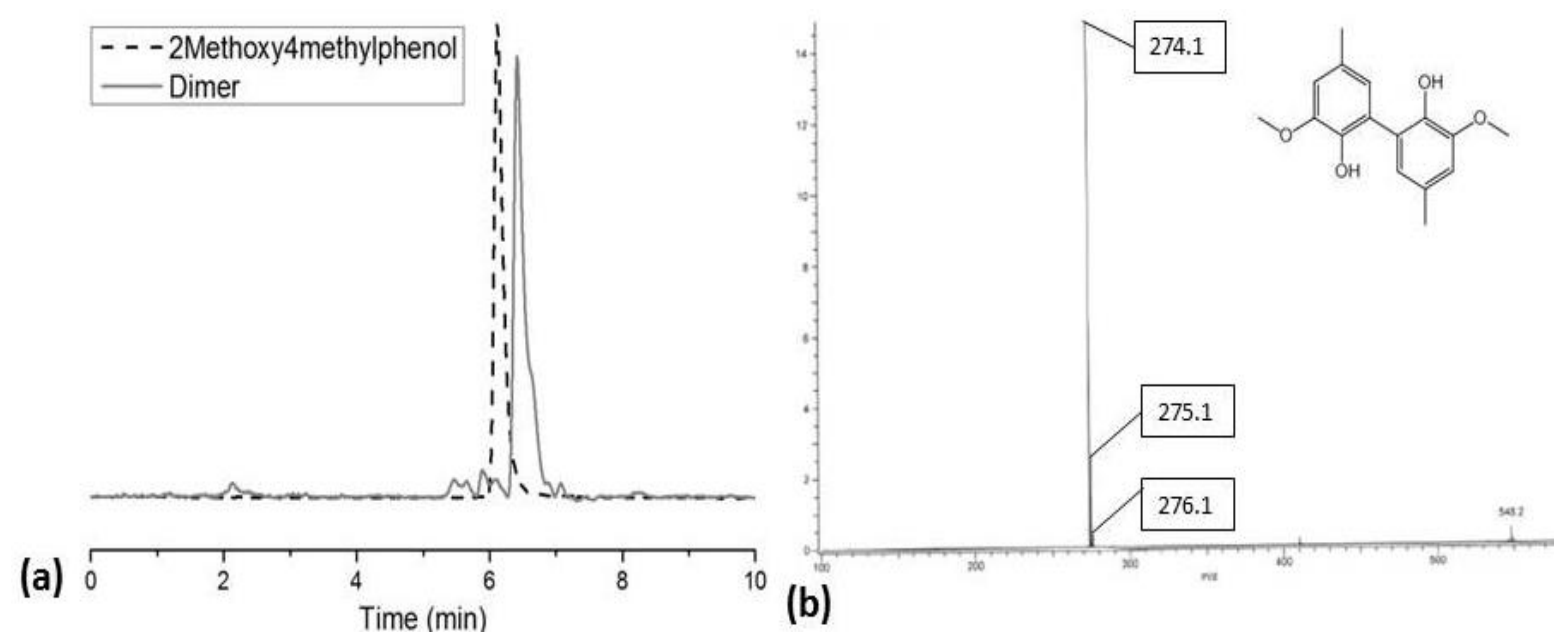

Figure S135: (a) HPLC profile of 2-methoxy-4-methylphenol (dashed line) and 2-methoxy-4-methylphenol dimer (5) (straight line), using a $\mathrm{C18}$ grafted silica column in acetonitrile with a UV detector, (b) Mass spectrum of 2-methoxy-4-methylphenol dimer (5) ionized by electronic impact, positive mode, direct introduction.
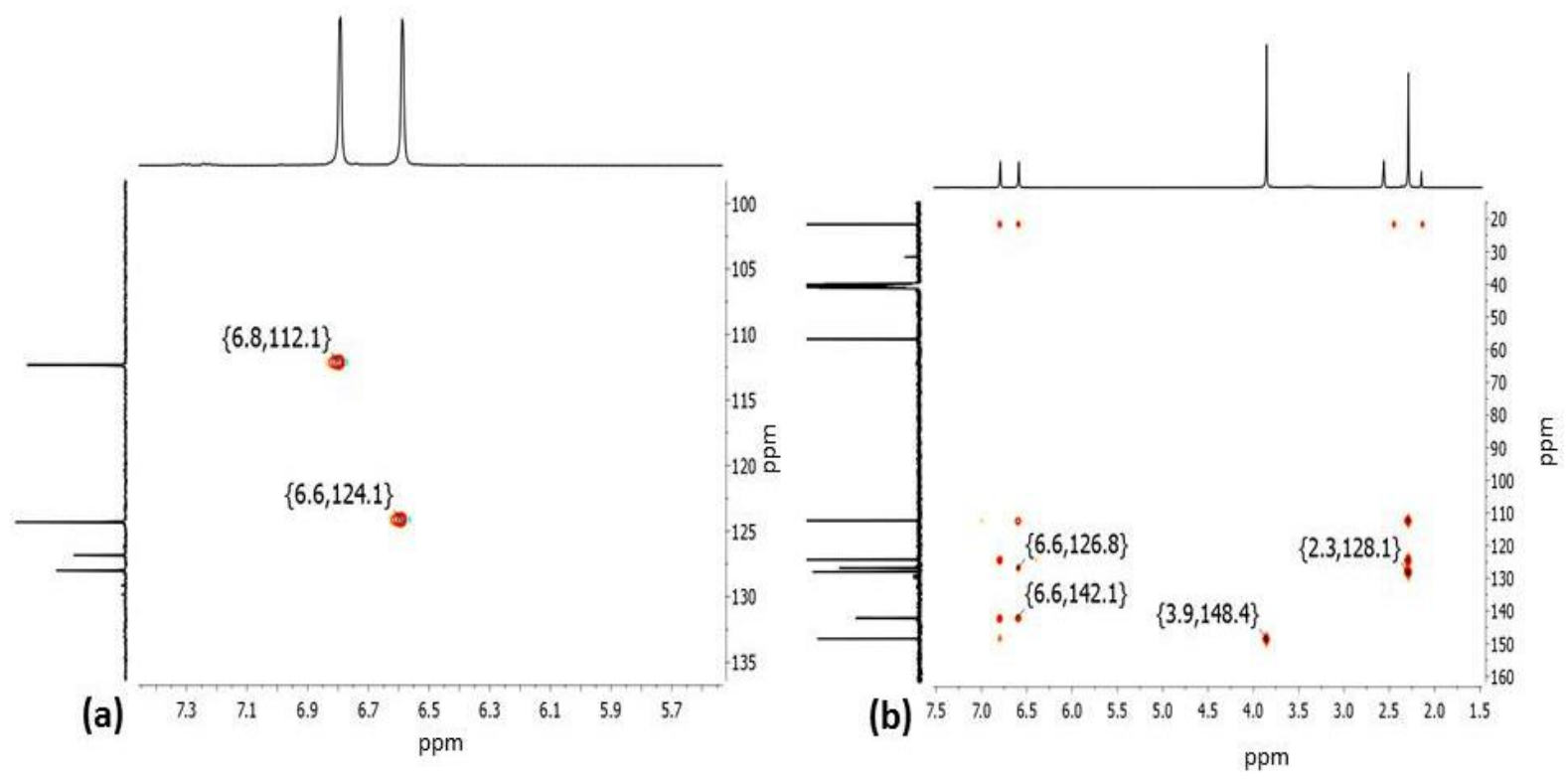

Figure S146 : HSQC (zoom on the aromatic region) (a) and HMBC (b) spectra of 2-methoxy-4methylphenol (5) in DMSO, at room temperature. 


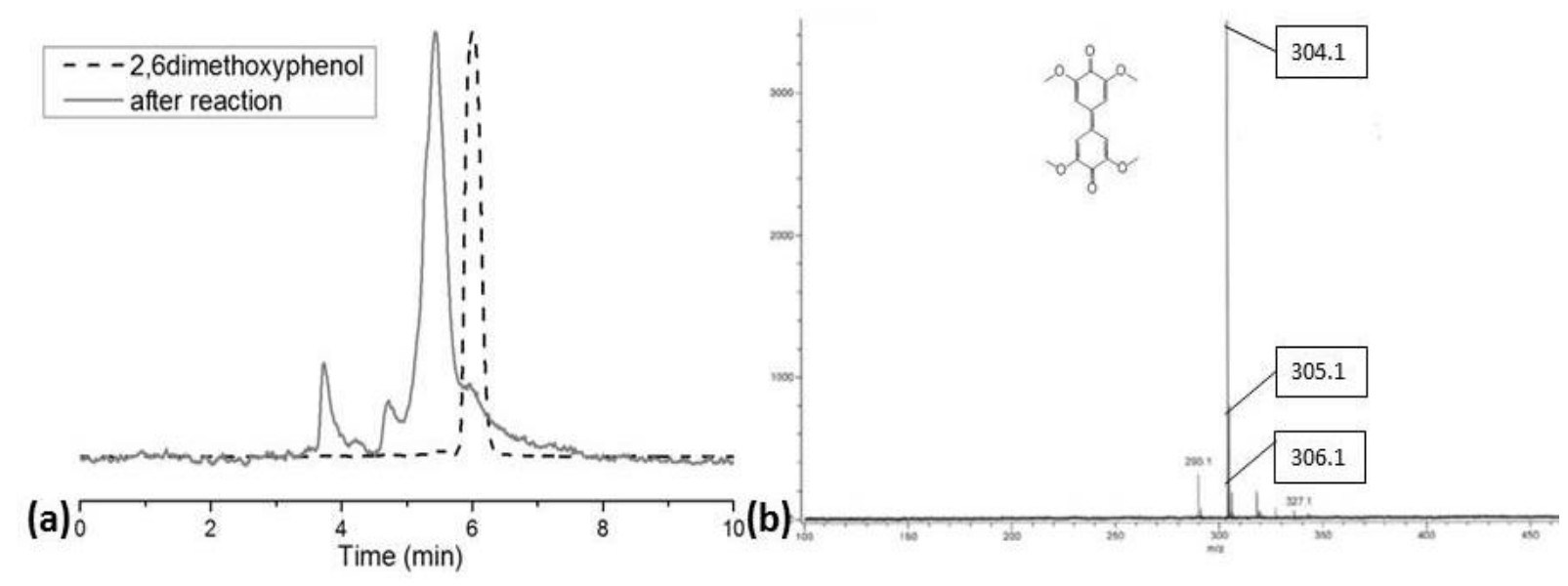

Figure S157: (a) HPLC profile of 2,6-dimethoxyphenol dimer (dashed line) and 2,6-dimethoxylphenol dimer (6) (straight line), using a C18 grafted silica column in acetonitrile with a UV detector, (b) Mass spectrum of 2,6-dimethoxylphenol dimer (6) ionized by electronic impact, positive mode, direct introduction.

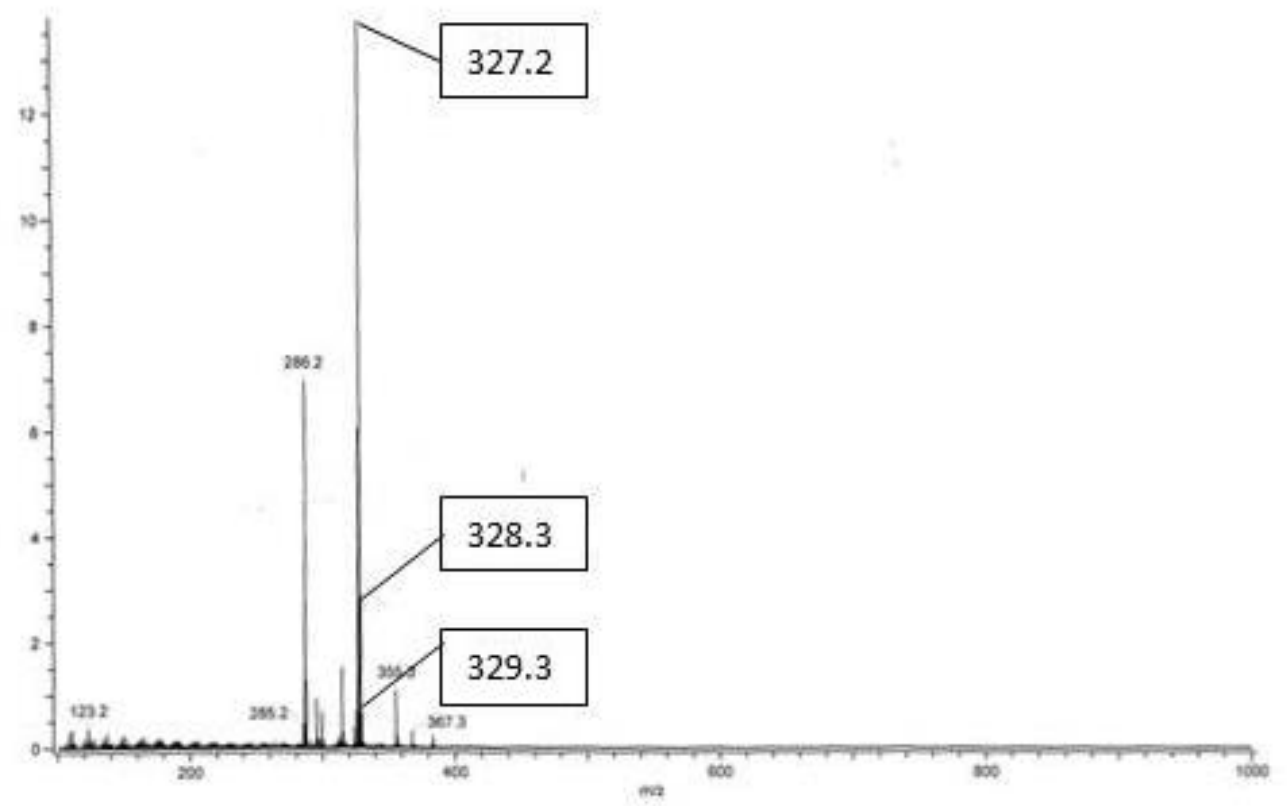

Figure S168: Mass spectrum of dieugenol (7) ionized by chemical ionization, positive mode direct introduction. 


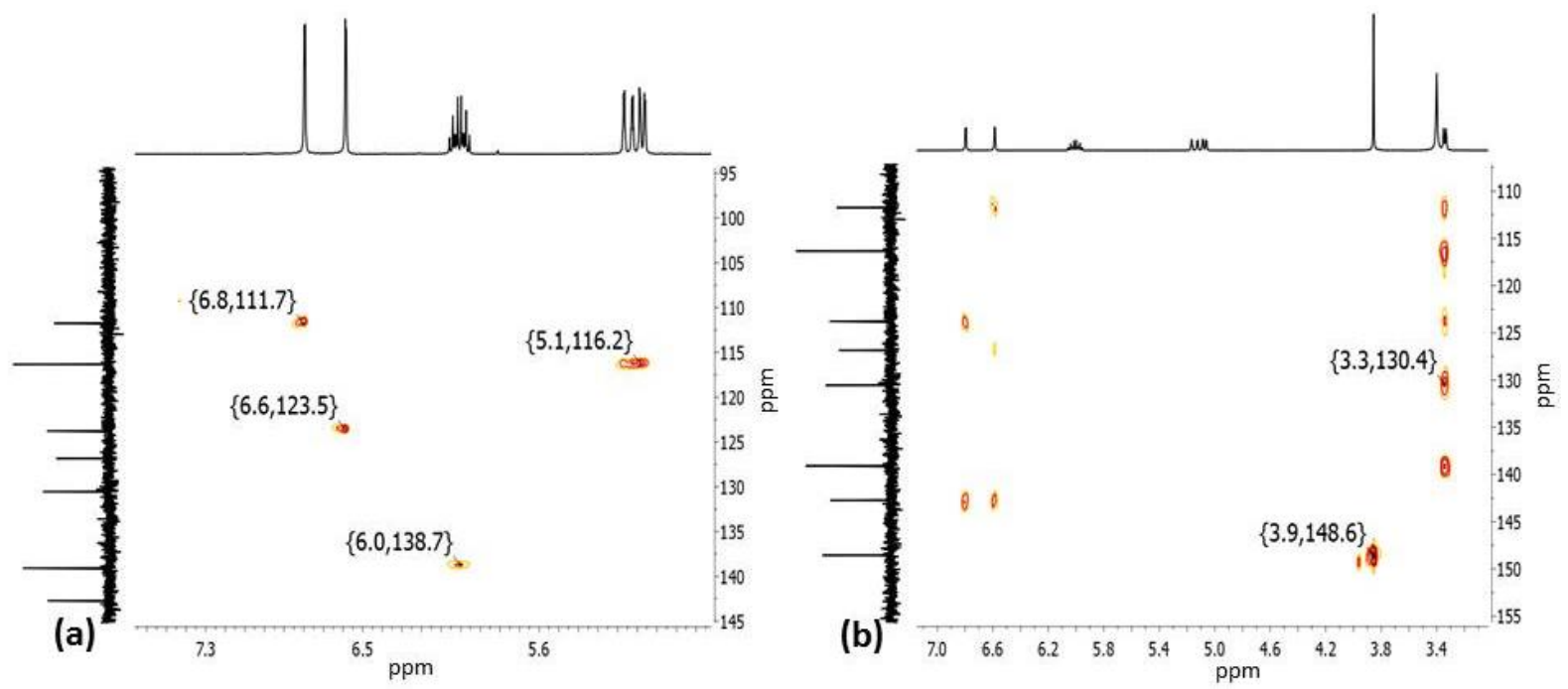

Figure S179: HSQC (zoom on the aromatic region) (a) and HMBC (b) spectra of dieugenol (7) in DMSO, at room temperature. 